\title{
EXPERIENCES MADE OF WOOL: VISUAL AND VERBAL METAPHORICAL RECONCEPTUALIZATION IN ADOPTION AND FOSTER CARE NARRATIVES
}

\author{
Coral Calvo-Maturana, University of Granada, Spain \\ Email: coralcm@ugr.es
}

Received: Septembre 15, 2021

Accepted: October 10, 2021

\begin{abstract}
This paper aims at exploring adoption and foster care discourse (AFD) so as to uncover the role of multimodal novel metaphor, and the resulting ad hoc concepts, in (re)addressing (AF) narratives. It specifically focuses on the picture book Speranza's Sweater (Pusey and Mello, 2018), and the extended conceptual metaphor A LIFE STORY (OF A CHILD [IN ADOPTION OR FOSTER CARE]) IS A SWEATER, as well as the net of minor related metaphors. These are analysed following Romero and Soria's (1997, 2005a, 2007, 2014 and 2016) as well as Forceville (1994, 2008)'s frameworks on, respectively, novel and multimodal metaphors. Dictionaries, thesauri, corpus-assisted tools, as well as close reading/viewing will inform the delineation of source and target domains. The paper illustrates and concludes the cognitive power of multimodal creative choices in relation to (AFD) to integrate children's past, present, and future experiences, while strengthening their sense of identity and belonging.

Keywords: Speranza's Sweater, Multimodality, Novel Metaphor, Visual Rhetorical Devices, Cognitive and Corpus Stylistics, Foster Care, Adoption, Picture Books.

Resumen: Este artículo pretende analizar el discurso de adopción y acogida (DAA) con la intención de identificar cuál es el papel de la metáfora creativa, y los resultantes conceptos ad hoc, en la (re)configuración de las narrativas (AA). En concreto, analiza el libro ilustrado Speranza's Sweater (Pusey y Mello 2018), y la metáfora conceptual extendida A LIFE STORY (OF A CHILD [IN ADOPTION OR FOSTER CARE]) IS A SWEATER, junto a la red de metáforas secundaria incluidas en la anterior. Estas quedan analizadas a partir de los marcos teóricos de Romero y Soria (1997, 2005a, 2007, 2014 and 2016) y Forceville (1994, 2008) aplicados, respectivamente, a la metáfora creativa y multimodal. Los diccionarios, tesauros, herramientas de corpus, así como la lectura/visionado detallado, informarán la delimitación de los campos fuente y objeto. El artículo muestra y concluye el poder cognitivo de los recursos creativos multimodales en relación a (AA) para integrar las experiencias pasadas, presentes, y futuras de los niños y niñas, fortaleciendo así su sentido de identidad y pertenencia.
\end{abstract}

Palabras clave: Speranza's Sweater, Multimodalidad, Metáfora Creativa, Recursos Pictóricos, Estilística Cognitiva y de Corpus, Acogida, Adopción, Libro Ilustrado. 


\section{INTRODUCTION}

Change is not always a choice
But you'll get used to it
And things will get easier...
I have a voice
I have a Mum

(From 'Change'. Eli, age 13.

The Collection CoramBAAF, 2017: 17)

This paper aims at shading light on how (multimodal) novel metaphors take part in the (re-)configuration of adoption and foster care discourse (AFD) in picture books. This research question involves the analysis of how they are constructed, and in which ways they help to enrich children' and adults' understanding of (AFD).

An answer is here provided in relation to the picture book Speranza's Sweater: A Child's Journey Through Foster Care and Adoption (SS), written in English language by Marcy Pusey and illustrated by Beatriz Mello (2018). The Story begins with Speranza as an adult telling her own life story to her son, upon him asking about a 'kinda plain' sweater her mother keeps. Their discussion in (free) direct speech (Leech and Short 1986, Short 1996) transports the reader in a flashback to Speranza's own story, in which Speranza tells about her experience in foster care and adoption in third person. The underlining metaphor A LIFE STORY (OF A CHILD [IN ADOPTION OR FOSTER CARE]) IS A SWEATER indeed tailors the narrative and embraces its meaningful understanding of 'family', 'home' and 'identity'.

The departing hypothesis in the analysis of Speranza's Sweater is that: (i) a comprehensive description of the multimodal semiotic means at play in the construction of the umbrella novel metaphor in the story is essential to understand its portrayal of adoption and foster care; and, (ii) there might be tendencies across picture books discussing adoption and foster care metaphorically in terms of the features that are foregrounded or added to the target domain by means of the creative choice of source domain/s, which might at the same time be subject to ad hoc reconfiguration. This second research question falls under the objectives of a bigger research project on the multimodal representation of adoption and foster care on which I am working at the moment which explores both children picture books (AFPB), and children's creative responses (AFCR).

Gilman (2009: 30) $)^{1}$, as clinical psychologist and author of the picture book Murphy's Three Homes, which narrates the experiences of a little puppy through different homes and shelters, underlines that the story she writes 'mirrors the experience of many children who have been in foster homes', and it does share concerns raised in Speranza's Sweater such as children's worry that they may do something wrong that would lead their foster parents to ask them to leave: 'My heart sunk. I had lost my last chance. I knew I would have to leave,

1 Part of the 'Note to Caregivers and Other Adults' (pp. 30-32), added as an appendix to the story. 
but I didn't want to show them that it made me sad' (Gilman 2009: 18). The scholar further highlights that the running theme of her book is 'helping a child build and maintain positive self-esteem in the face of the adversity experienced by most foster children' (Gilman 2009: $30)^{2}$. This sense of self-esteem and belonging can be seen in Eli's words selected as opening of this article: 'Change is not always a choice [...] But I have a voice. I have a Mum' (The Collection CoramBAAF, 2017: 17). The parallel structure here encourages the reader to understand the persona's 'voice' in relation to her 'mum', and viceversa.

It is necessary to understand these rhetorical uses within the discourse in which they emerge, not only due to the semiotic affordances that are inherent to that particular discourse (Gibson 1979, in Forceville 2020: 2), but also due to the audience they address, children in this case. As the author's note highlight 'while Speranza's story is unique to her, every child will relate to her feelings of confusion, longing, fear, worry, excitement, and hope'the name of the protagonist in Italian language (Pusey 2018). In this respect, we should also bear in mind the role of the adult reader, who Painter (2009) refers to as co-reader, in guiding the child to read/visualise and understand the story, including the interplay of textual and visual mode. In this sense, the multimodal nature of picture books not only enhances the potential richness of the metaphor but also makes it more accessible to a reader with probably initial skills (Painter 2007: 40).

The analysis of novel and pictorial metaphors is carried out applying, respectively, Romero and Soria's (1997, 2005a, 2007, 2014 and 2016) as well as Forceville (1994, 2008) and Forceville and Urios-Aparisi (2009)'s frameworks. These are specifically applied to picture books (Calvo-Maturana 2020 and Calvo-Maturana and Forceville, in press) aiming at identify how meaning is visually created in Speranza's Sweater in the context of (AFD). The multimodal study of the metaphor underlining the story requires likewise the exploration of other visual rhetorical devices such as verbal and visual metonymy (Romero and Soria 2005b and Moya Guijarro 2015) or visual parallelism.

In this paper, the term 'adoption and foster care narratives' is used to make reference to those multimodal texts that evolve around the concept of adoption and foster care, as defined in the glossary that accompanies the picture book object of study. ${ }^{3}$ 'To adopt' is thus 'to legally take a child who was not born to you and raise them as your own' (Pusey and Mello 2018) and 'to foster care' involves 'temporary care for children whose parents are unable to look after them' (Ibidem).

Following the introduction, the paper discusses in further detail the method of analysis in relation to both framework and tools. The analysis and discussion is then presented identifying the umbrella metaphor as well as the minor ones that evolve around it, strengthening meaning while at the same time signposting key elements in the transferring process. The conclusion alludes to the methods in analysing multimodal texts as well as the role of Speranza's Sweater in the multimodal structuring of adoption and foster care discourse.

\section{See Footnote (1).}

3 This additional material shows the way in which the book is also thought of as a safe space or conversation starter for children to be able to discuss, comprehend, and embrace various types of families, independently of the type of family they were born in. 


\section{METHOD}

The methodology in this paper addresses the analysis of textual and visual modes drawing on Romero and Soria's (1997, 2005a, 2007, 2014 and 2016) as well as Forceville (1994, 2008) and Forceville and Urios-Aparisi (2009)'s proposals in relation to, respectively, novel and pictorial metaphors. It likewise acknowledges other visual rhetorical devices that are at play in the construction of the main metaphor in Speranza's Sweater.

This paper thus studies the delimitation of ad hoc metaphorical concepts to understand how they take part in meaning creation in Speranza's Sweater, and ultimately, identifying the uses and semantic value of novel metaphors in adoption and foster care discourse. For this purpose, Keating and Soria (2019) is likewise a work of reference on the application of Romero and Soria's framework $(1997,2016)$ in relation to the way in which populist binary understanding of the world is presented through metaphorical discourse. The study thus defines the framework while at the same time showing the potential of novel metaphor in the configuration of a certain discourse by means of foregrounding certain features of the target domain while maybe strategically blurring others. Furthermore, Keating and Soria (2019) prove the possibility of identifying trends in the process of reconceptualising target domains within a certain discourse.

Romero and Soria $(1997,2016$ : 146, 154-169) understand metaphor as a mandatory primary pragmatic process of transfer. It consequently takes part in the definition of "what is said' and plays a major role in deriving a truth-evaluable proposition. In particular, the scholars underline the following two requirements to identify an utterance as metaphorical: contextual abnormality and conceptual contrast. The former alludes to a conflict in our conceptual system as a result of identifying a linguistic item in an (extra)linguistic context which does not answer to our established categorisation. The latter refers to the identification of two separate domains, the target domain or the one we are talking about and the source domain or the one from which certain features are selected and applied to the target. The process of interpreting the metaphor involves the delineation of the domains and mapping. The domains are made of vocabulary and structural constraints; i.e. the terms inherently associated to the definition of the concepts together with the sentences that guide on how these terms are related to describe the concept. A later process of transfer, a case of 'language shifting', results in a context of interpretation whereby the structural constraints activated in the source domain reconfigure the target domain into an ad hoc concept, a temporary reconceptualization in that newly created context in which metaphorical thinking is a prerequisite.

Metaphorical meanings cannot exist without the metaphorical thinking from which they are conceived and thus the power of metaphor is not lost in their elaboration. Taking into account these metaphorical meanings, metaphorical utterances can convey propositional contents to agree or disagree, they can provide information that interlocutors add to the record (Romero and Soria 2016: 155, emphasis added).

It is precisely the "power" of metaphor and its role in the creation of "propositional contents" that is assessed in this article in relation to the particular portrayal of (AFD), and 
(re)-addressing of children's concerns and emotions when being placed in the adoption and foster care system.

A key aspect in the scholars' model of novel metaphors, as highlighted in Keating and Soria (2019), is that it is not only the target domain which is subject to a reconceptualization, the source domain is also on many occasions specially restructured into an ad hoc concept for that particular conversational exchange.

The construction of the metaphorical context in the interpretation of novel metaphorical utterances often requires a source domain which is also constructed in an ad hoc manner. In this way, a very ad hoc portrayal of the source domain allows a very rich ad hoc and specific metaphorical characterisation of the target. The evidence provided by the speaker about the ad hoc source domain guides the hearer's construction of the mapping as intended (Keating and Soria 2019: 212, emphasis added).

A comprehensive interpretation of novel metaphors therefore requires on many occasions the identification of the 'evidence' which may add further vocabulary and structural constraints in the delineation of the source domain or favour the activation of certain features in the transferring process. Understanding the source domain as also potentially subject of re-conceptualisation may consequently enrich the interpretation of the metaphor under analysis and its cognitive power to reconfigure our worldview.

In this paper, the delineation of domains as ready-made concepts, i.e. as lexicalised in our conceptual system, will be carried out making use of The Oxford English Dictionary (OED) and the corpus $i$ Web: The Intelligent Web-based Corpus (Mark Davies), so as to acknowledge, respectively, the terms as gathered diachronically by lexicographers and their everyday contemporary use by speakers on the web. In particular, the iWeb corpus gathers 14 billion words in English language, including the dialect of 6 countries, and a selection of the Web content of the year 2017. In a second stage, the outline of the source domain will require an analysis of the 'evidence' provided in the text, which in the case of the picture book is both textual and visual, so as to specify its ad hoc multimodal configuration. The textual exploration of the text in Speranza's Sweater (SS) will be carried out through the software AntConc (Lawrence 2014), keying in the text in electronic format in order to explore wordlist frequencies and KWIC. The colourful display of those words to either the left or the right hand-side of the node word is here useful so as to unveil patterns of use which may be meaningful to the interpretation of the overarching metaphor. The main corpus SS has been divided into the sub-corpora: dedication ( $\mathrm{SSd}$ ), body of the text (SSbt), glossary (SSg), author's note (SSan), and back cover (SSbc). The rationale for this division is that, as the analysis will show, sections outside the body of the text take part in the construction of the overarching metaphor, activating features of the source domain and hinting on minor related metaphors. Moreover, the division allows to identify which sub-corpus the KWIC is part of, displayed on the right-hand side of AntConc tool. In this way, further research could be done in relation to the target audience of the text, as whereas the body text is addressed to the child reader, the back cover tends to prioritise on the adult reader.

The iWeb was likewise chosen due to the 'Browse' tool added to its exploration platform, which easily computes the collocates of the node word, providing in this way the terms linked to that particular domain, and a way to identify its semantic preference (Flowerdew 2009: 
332 ); i.e. the semantic fields that evolve around the word object of study and thus define the domain. In this platform, a collocate is identified within a span of $4: 4$, i.e. four words to either the left or right hand side of the word object of study, and the Mutual Information score is set to a frequency of [2]. The search was conducted adding the word-form object of study, specifying its word-class and clicking on 'meaning' - 'definition' so that the software would identify words that included the node word in their definitions.

Once the search is conducted, the information provided includes the list of most frequent collocates classified according to their word class. A sample of the lines of concordances is displayed below on the same window, though specific KWIC can be explored further by clicking on '(more)', next to the headline 'collocates'. This option links the user to a new page with a more detailed list of collocates and their associated KWIC. Collocates are displayed here in darker or lighter shades of colour depending on a more or less frequent co-occurrence. The analysis of the KWIC is essential to understand the syntactic and lexico-semantic behaviour of each collocate in relation to the node word so that it is not biased by our intuitions. For instance, in the list of collocates for 'knitter', the word 'gift' was intuitively thought to be associated to those gifts provided by knitters, though in the corpus it is mainly linked to the cluster 'gifts for knitters' in which knitters are the beneficiaries of those gifts and not the providers. Reference to relevant KWIC is included in footnotes to discuss patterns or whenever a more detailed search was necessary so as to disambiguate meaning.

As for multimodal metaphors, these are understood as those metaphors in which more than one mode is at play in the construction of the source and target domains; i.e. the domains are fully or to some extent outlined in different modes (Forceville 1994 and 2008, Forceville and Urios-Aparisi 2009). The process of analysing those pictorial and multimodal representations of metaphors would likewise involve a verbalisation process. This is, as Forceville (1994) highlights in relation to paintings, a key process in the analysis as it could determine the way the metaphor is understood, maybe narrowing it in a negative sense, as it is complex to establish "unequivocal verbalisations of the metaphors contained in these [surrealist works of art] artistic representations."

\section{ANALYSIS AND DISCUSSION}

The picture book Speranza's Sweater is carefully woven through the multimodal novel metaphor A LIFE STORY (OF A CHILD [IN ADOPTION OR FOSTER CARE]) IS A SWEATER. A comprehensive analysis of this metaphor requires likewise the study of a series of minor metaphors that support the former and highlight key features in the source domain that should be activated and transferred to the reconfiguration of the target domain. These are A LIFE EXPERIENCE IS A YARN, A CARE GIVER IS A KNITTER, SPERANZA'S PAST IS SWEATER, SPERANZA'S PAST, PRESENT AND FUTURE, IS SWEATER ${ }_{2}$, and A LIFE STORY THAT FULFILLS THE EXPERIENCER IS A SWEATER FITTING WELL.

When identifying the metaphor, and in relation to the contextual abnormality, our conceptual system does not include the span of time from which an entity is born to the time in which it dies, or any other moment in her/his life, as part of the semantic value of 'sweater', neither if specifically addressing adoption and foster care. Moreover, the definition 
of 'yarn' does not seem at first sight to be connected to the area of 'life experiences'4; a 'knitter' is not included in the context of 'caregivers', and we are not used to understand a sweater to fit in any other way than simply physically or maybe, already as an extension of meaning, in relation to a person's character.

As for the conceptual contrast of target and source domain, the overarching metaphor A LIFE STORY (OF A CHILD [IN ADOPTION OR FOSTER CARE]) IS A SWEATER makes it necessary to distinguish two sweaters in the story as source domains, and their related targets. As such, sweater, woven in yellow yarn, has as target Speranza's past experiences, as it is the one that the protagonist owns when living at her birth home and accompanies her all throughout the process of foster care and adoption. It is a yellow and blue yarn -the latter of Speranza's choice- that relates the experiences of the source domain sweater ${ }_{2}$, whose features are applied to Speranza's past, present, and future (with her own son). ${ }^{5}$ The helper here is the grandmother (Greimas, Bal 2017: 170, as mentioned in Calvo-Maturana and Forceville, in press), standing for all 'caregivers' or adults in a position to help a child; all of them target of the source domain 'knitter'. The conceptual contrast in relation to the minor metaphors is specified along different sections when applicable.

This section details the analysis and discussion of the overarching and associated metaphors, as well as other multimodal devices that contribute to its meaning-making.

\subsection{Spinning Life ${ }^{6}$}

One of the minor metaphors linked to the overarching metaphor in SS can be phrased as A LIFE EXPERIENCE IS A YARN. Following the evidence from the $i$ Web (Mark Davies), whenever the linguistic term 'yarn' is used, ${ }^{7}$ it is very unlikely that it is in the context of a 'life experience'. Nonetheless, this metaphorical use is already part of the English language as recorded in the OED, dating back to the early $17^{\text {th }} \mathrm{C}$ and Shakespeare's works. ${ }^{8}$ In

4 The Roget's Thesaurus nonetheless establishes a connection between 'yarn' and 'story' in senses other than 'filament', including 'falsehood', 'untruth', 'description', 'wit' and 'laughingstock'. It does seem that this metaphor is partly lexicalised, though exploited in a different discourse and manner in SS.

5 The distinction between the two sweaters is textually made explicit as the child asks Speranza: "The sweater?!", in which the use of italics shows the marked pronunciation of 'the' so as to refer to an specific sweater, sweater 2 , the one which catches the child's attention. To this question, Speranza replies: "Sorta," and encourages her child to keep listening. We in fact later learn that it is 'sorta' the same sweater as its foundations are to be found in sweater 1 .

6 Glasgow University launched a conference entitled 'Spinning Scotland' in 2008, with selected papers published on a special issue of $e$-sharp.

7 The terms 'threads' and 'strands' could likewise be explored in terms of collocates as they are vehicles explicitly used in SSbc

8 The OED distinguishes the following sense for 'yarn': 'Originally, spun fibre, as of cotton, silk, wool, flax; now, usually, fibre spun and prepared for use in weaving, knitting, the manufacture of sewing-thread, etc'. The following associated figurative sense matches the one in Speranza's Story: 'figurative.

a1616 W. ShaKeSPEARE All's Well that ends Well (1623) IV. iii. 74 The webbe of our life, is of a mingled yarne, good and ill together. T. DE Quincey Caesars in Blackwood's Edinb. Mag. Oct. 604/1 In the mingled yarn of human life. 
Speranza's Sweater, in contrast to the contemporary uses recorded in $i$ Web (Mark Davies), the 'yarn' is also used as source domain from which to describe the target 'life experience'.

The semantic preference for 'yarn' is determined by its collocates (Graph 1) which evolve around the idea of physical appearance ('color', 'brightly', 'weight', 'thick'), quality ('beautiful', 'fine'), shape ('ball', 'piece', 'fabric'), texture ['soft', ('super') 'bulky', 'chunky'], materials ('cotton', 'acrylic'), tools to work with it ('needle', 'hook') and how to work on it ('tightly', 'tight', 'beautifully', 'loosely', 'horizontally'). As can be noticed, none of the semantic fields involve the idea of 'life experiences'.

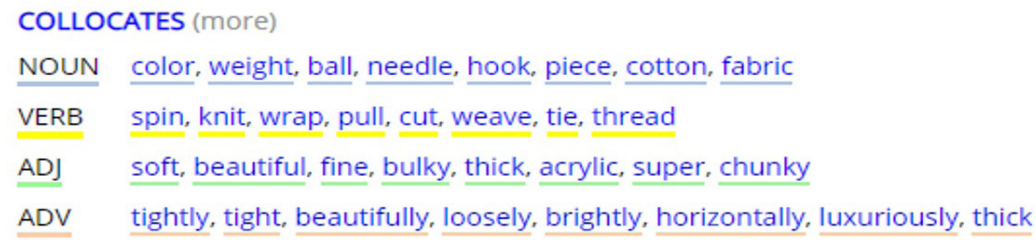

Graph 1. Yarn's collocates (iWeb, Mark Davies).

If however we explore the textual evidence in SS (KWIC 1), we notice a difference in the co-occurrence which is key in the understanding of the metaphor, it includes the wordforms: 'old', 'new', 'she' [referring to Grandmother], 'Speranza', 'her' [referring to Speranza], 'picked', and 'color'.

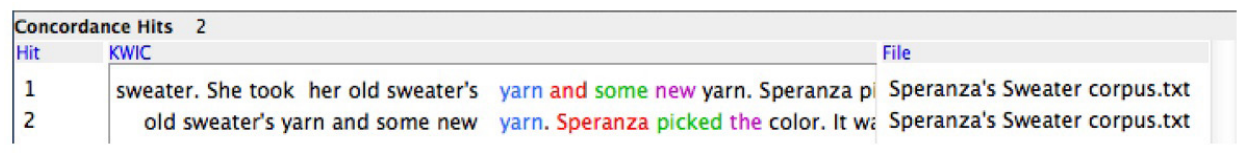

KWIC 1. 'Yarn' in SS (AntConc, Lawrence 2014).

In these lines of concordances, both grandmother and Speranza are agents. The adjectives 'old' and 'new' refer to Speranza's past and present, in which, essential to notice, the borderline of 'past' versus 'present' is marked by the moment in which Speranza is adopted by her 'forever family'. The glossary in the book defines the concept 'forever family' as: 'A family who chooses to be parents and siblings of a child forever.' In the same definition, we can see this is a shared decision that involves every member of the family, adults and children. We likewise notice the relevance of time as well as another key term in adoption and foster care discourse: 'to choose', which is also part of the co-occurrences in 'yarn': 'picked' (KWIC 1). There is thus a mutual conscious decision to belong to the same family, which is likewise made evident on the adoption day ceremony through Judge Cordoza's questions, addressed to Speranza and her foster parents in indirect speech, filtered by the narrator, i.e. by adult Speranza, as well as the addressee's answers in direct speech (1).

(1) "One day Speranza and her family went to court. A judge asked if she wanted her foster mom and dad to be her parents forever. 
'Yes,' she said.

Judge Cordoza asked her foster parents if they wanted her as their daughter forever. They said 'yes' too. The judge gave her a new birth certificate with her new name on it!” (Pusey 2018: 21).

The use of direct speech in (1) so as to hear the actual voices of Speranza and her adoptive parents in their commitment to care for each other, foregrounds their vow and the fact that it is a voluntary and personal will. Furthermore, Speranza's answer is foregrounded by being graphologically separated from the other paragraphs and framed in the centre of the text.

Finally, as for 'old' and 'new' (respectively, KWIC 2 and KWIC 3), there is a total of two occurrences versus nine occurrences in the corpus, which already quantitatively highlights the emphasis through the word-form 'new' on both the constant changes that Speranza has to face -in line with the opening quote, as well as the experiences that await her as part of her 'forever family'. The adjective 'old' though, via its co-occurrence with word-forms like 'keep' and 'special' (KWIC 2) shade the word with a positive semantic prosody (Louw 1997), which likewise teaches the value of 'old' items, in this case of an emotional nature.

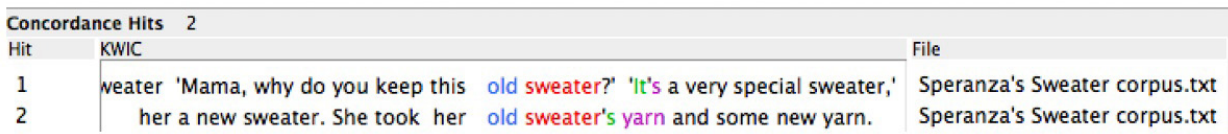

KWIC 2. 'Old' in SS (AntConc, Lawrence 2014).

The adjective 'new', which characterises sweater ${ }_{2}$ is key in the story. In fact, it is repeated on nine occasions in a book with a total of 398 word types [adding all sub-corpora] (KWIC 3).

'New' signposts the changes from Speranza's past to her present. The metaphorical reconfiguration of sweater ${ }_{2}$ as 'Speranza's life' is foregrounded by the parallel structure of NPs in which the pre-modifier is the adjective 'new': (2)-(10).

(2) new birth certificate

(3) new clothes

(4) new daughter

(5) new family

(6) new name

(7) new state

(8) new story

(9) new sweater

(10) new yarn 


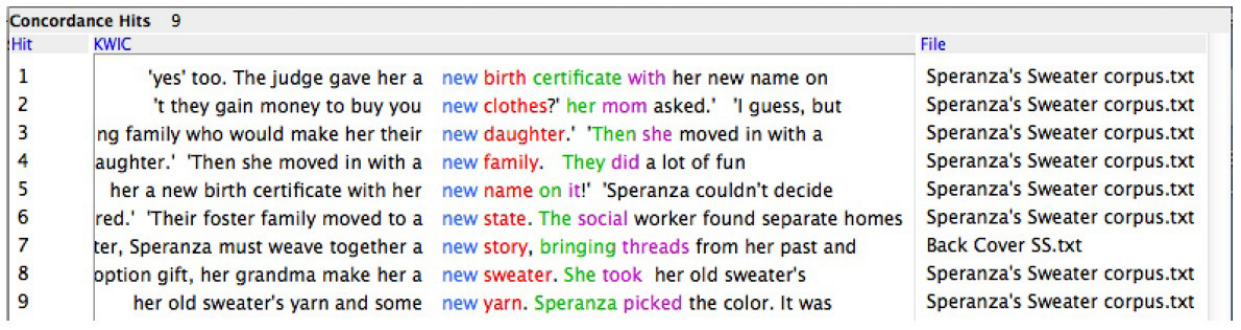

KWIC 3. 'New' in SS (AntConc, Lawrence 2014).

Even though the cases are scattered along the text, they are frequent enough for the reader to notice the parallelism across them. The simple repetition of the grammatical structure as well as the lexical repetition of 'new' encourages the reader to observe them, while at the same time focusing on those lexical choices that differ and trying to establish semantic connections amongst them. When analysing them, they all refer to 'beginnings' in Speranza's life, ${ }^{9}$ which can well represent a challenge that the child or young adult in the adoption and foster care system may have to face. In fact, it is when 'their foster family moved to a new state' that Speranza and her two brothers were set apart to be relocated in other foster parents' homes (Illustration 1). We likewise notice that the features that differ [cases (2)- (10)] are precisely those that may define a person's identity or well-being, such as the 'family', 'name', 'country' and basic needs such as 'clothing'. As stated in the book back cover: 'Like her unraveled sweater, Speranza must weave together a new story, bringing threads from her past and strands from her present, into a future of love, family, and the true meaning of home' (Pusey 2018: back cover).

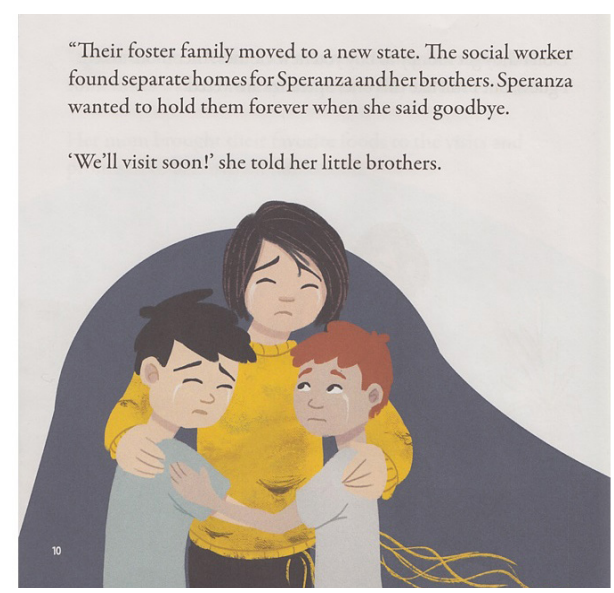

Illustration 1. Triangle composition of Speranza and her two brothers.

This is the moment of farewell when they have to move to different foster parents' houses.

(C) Marcy Pusey. Illustrated by Beatriz Mello (2018)

9 Notice the name of The Collection CoramBAAF in 2017, including both keywords in (AFD): 'new' and 'beginnings': 'New Beginnings and Other Writings on Being in Care'. 
In Illustration 1, Speranza and her two younger brothers are hugging each other in a triangle composition (see Calvo-Maturana and Forceville, in press), Speranza standing at the centre and higher angle. ${ }^{10}$ The three participants are connected-physical intimacy, their arms and hands drawing a continuous circle. Speranza's arms, and by extension, sweater hugs the two brothers, for whom Speranza fulfils the care-giver role. The threads have significantly grown apart, as Speranza looses a significant part of her home, the daily living with her brothers. The waved dark blue background which functions as frame of the scene, and departs from a lighter blue of the former scene/spread, may be the result of the participants' tears or maybe echo in its intensity the participants' emotions.

As shown in KWIC 3, other collocates evolving around the node word 'new' are likewise essential to interpret the meaning of this word-form in relation to the storyline and the metaphorical understanding of sweater. In particular, the material process 'picked' (line 9 in $K W I C$ 3), in which Speranza is the agent, highlights that Speranza has a major role in this new turn in her life; in contrast to former changes in which she was patient, subject to other people's decisions (line 6 in KWIC 3). In this latter case, we see the co-occurrence of 'social worker', as a helper in a moment in which external life circumstances left Speranza in a vulnerable situation.

'Life experience' and 'Life experiences' are two of the clusters featuring as part of the search for the word-form 'life', with respectively, 15832 and 17670 occurrences in the corpus. Exploring the first word to the left hand-side that qualifies 'life experience' in the platform random selection of 100 lines of concordances, we find the terms that evolve around this compound, as specified in Table $1, \mathrm{~V}_{\mathrm{t}}$. The analysis of the random list of 100 line of concordances in the cluster with the plural form 'life experiences' provides a similar co-occurrence in relation to the above uses with alternative vocabulary, also specified in the description of the domain (Table 1). There is maybe an additional use in contrast to the singular form qualifying 'life experiences' as either 'formal' or 'informal'.

\begin{tabular}{|c|c|}
\hline Yarn & Life experience \\
\hline $\begin{array}{l}\text { Ds }=<\mathrm{V}+\mathrm{S}> \\
\text { Vs= 'fibre', 'spun', 'cotton', 'silk', 'wool', } \\
\text { 'flax', 'color', 'brightly', 'weight', 'thick', } \\
\text { 'beautiful', 'fine', 'ball', 'new', 'old', } \\
\text { 'picked', etc } \\
\mathrm{Ss}= \\
(1 \mathrm{~s})=\text { A fibre form by spinning } \\
(2 \mathrm{~s})=\text { The fibre can be made of cotton, silk, } \\
\text { wool or flax. } \\
(3 \mathrm{~s})=\text { The fibre is used in weaving, knitting, } \\
\text { sewing, etc. }\end{array}$ & $\begin{array}{l}\mathrm{Dt}=<\mathrm{V}+\mathrm{S}> \\
\mathrm{Vt}=\text { 'your'/ 'their', 'my (own)', 'individual', } \\
\text { 'personal', 'collective', 'shared', 'campus', } \\
\text { 'student', 'residence', 'working-class', } \\
\text { 'formative', 'sufficient', 'more', 'a lot of', } \\
\text { 'some', 'appropriate', 'without', 'rich', } \\
\text { 'productive', 'diverse', 'range', 'fantastic', } \\
\text { 'enriching', 'valuable', 'unique', 'healthy', } \\
\text { 'normal', 'good', 'great', 'significant', } \\
\text { 'relevant', 'valuable', 'creative', 'major' } \\
\text { 'real', 'early', 'mature', 'past', 'previous', } \\
\text { 'night', 'new,' 'different', 'other', } \\
\text { 'alternative', 'formal', 'informal'. }\end{array}$ \\
\hline
\end{tabular}

continue next page

10 The triangle composition could maybe be related to the role of 'the list of three' in textual mode. 


\begin{tabular}{|c|c|}
\hline Yarn & Life experience \\
\hline $\begin{array}{l}(4 s)=\text { It can differ in terms of physical } \\
\text { appearance as for its color, weight or } \\
\text { thickness. [textual/visual] } \\
(5 \mathrm{~s})=\text { The yarn can be praised due to its } \\
\text { quality, as beautiful or fine. } \\
\text { ( } 6 \mathrm{~s})=\text { It is normally saved as a ball and later } \\
\text { cut in pieces. } \\
(7 \mathrm{~s})=\text { The yarn has different texture, soft, } \\
\text { (super)bulky, chunky, ... } \\
(8 \mathrm{~s})=\text { Different tools can be used to work with } \\
\text { it such as a needle or hook. } \\
(9 \mathrm{~s})=\text { It can be woven tightly or loosely, } \\
\text { and stretched horizontally, vertically or } \\
\text { diagonally. [textual/visual] } \\
(10 \mathrm{~s})=\text { Yarns necessarily need a knitter, a } \\
\text { loom, or some expert who can train a younger } \\
\text { knitter, so as to form patterns. } \\
(11 \mathrm{~s})=\text { Yarns can be old or new. }{ }^{11} \\
\text { (12s)= Yarns can be picked. }\end{array}$ & $\begin{array}{l}\mathrm{St}= \\
(1 \mathrm{t})=\mathrm{It} \text { is understood in relation to the person } \\
\text { who lives it, either as shared experience or } \\
\text { personal. } \\
(2 \mathrm{t})=\text { It might be related to student life or } \\
\text { work. } \\
(3 \mathrm{t})=\text { It is something that is measurable in a } \\
\text { way that can be gained or assessed against a } \\
\text { social standard. } \\
(4 \mathrm{t})=\text { A 'life experience' can also be praised } \\
\text { to different degrees as something enriching, } \\
\text { enjoyable or healthy. Whenever it is highly } \\
\text { praised, it is defined as having a 'real' vs. 'no } \\
\text { real' experience. } \\
(5 \mathrm{t})=\text { A life experience is a period of time } \\
\text { in relation to the person's life or a temporal } \\
\text { frame in the day. } \\
(6 \mathrm{t})=\text { It is likewise qualified as for its } \\
\text { distinctive nature in contrast with former } \\
\text { ones. } \\
(7 \mathrm{~s})=\text { They can be either 'formal' or } \\
\text { 'informal'. } \\
(8 \mathrm{~s})=\text { Some life experiences can be chosen. }\end{array}$ \\
\hline
\end{tabular}

Table 1. 'Yarn' and 'life experience' domains.

The lines highlighted in bold letters in Table 1 are the ones activated in the transferring process, while the others are downplayed. The following is thus the restructured $D_{t}$ or $D_{t}^{M}$ in LIFE EXPERIENCE AS YARN, reformulating the structural constraints in Dt via the relevant terms in Ds, as well as applying particular characteristics of Ds which might not be normally foregrounded in the lexicalized understanding of Dt.

$\left[1_{t}^{\mathrm{M}}\right]$ Life experiences are made by spinning/ undergoing life.

$\left[2{ }_{t}{ }^{\mathrm{M}}\right]$ Life experiences are used in knitting/creating our lives.

$\left[3_{t}{ }^{M}\right]$ Life experiences can differ as for the extent to which they are enriching, the time in which they are lived- being 'old' or 'new', their nature in contrast to former ones, or whether they are formal or informal.

$\left[4_{t}{ }^{\mathrm{M}}\right]$ Life experiences are of a different nature, some of them softer/kinder than others, or of different colours.

$\left[5_{t}{ }^{M}\right]$ Some life experiences can be picked.

11 The structural constraints (11s) and (12s) have been added following the evidence in SS, which leads to activating certain specific features of 'yarn'. 
$\left[6_{t}{ }^{\mathrm{M}}\right]$ Life experiences can be interconnected tightly or loosely. They might be stretched along time or across other experiences.

$\left[7_{t}^{\mathrm{M}}\right]$ Life experiences need a person to make sense of them into a life. Sometimes it can be the own experiencer, sometimes an experienced person would need to guide the experiencer.

\title{
3.2 Care and Handicraft Uniting Life Experiences
}

The evidence for the minor metaphor A CARE GIVER (GRANDMOTHER/HELPER) IS A KNITTER can be identified on the dedication page: "To every child whose story is in the Knitter's hand: You are loved." 12 Here, the target domain can be associated to Speranza's grandmother and by extension, any caregiver or adult in a position of providing care, ${ }^{13}$ while the source domain is 'knitter'. The analysis of both domains, following the OED definition as well as the evidence of the words that co-occur with both word-forms in $i$ Web (Graph 2 and Graph 3), is detailed in Table 2.

As can be seen in Graph 2, the semantic preference of 'knitter' is defined by the lexical sets linked to materials ('yarn'), tools ('needle', 'spinner', 'loom'), levels ('beginner', 'experienced', 'avid', 'advanced', 'intermediate', 'skilled'), techniques ('pattern', 'tight'), results or products ('sock', 'gift'), action/field ('knitting', 'knit', 'stich', 'crochet', 'sew', 'spin'), appreciation ('fairly', 'proudly', 'pride', 'wonderful'), body parts or anatomy ('hand'), location ('everywhere', 'nationwide'), inclusivity ('fellow', 'alike') ${ }^{14}$, ways of working ('busily'). ${ }^{15}$

\author{
COLLOCATES (more) \\ NOUN yarn, beginner, pattern, sock, needle, knitting, gift, spinner \\ VERB knit, stitch, crochet, pride, hand, loom, sew, spin \\ ADJ experienced, avid, advanced, fellow, intermediate, tight, skilled, wonderful \\ ADV alike, fairly, everywhere, nationwide, proudly, busily, without, alright
}

Graph 2. Knitter's collocates (iWeb, Mark Davies).

\footnotetext{
12 The OED defines 'knitter', in the sense that applies to the story, as: 'One who or that which ties, knots, unites, or closely joins together. literal and figurative. [...] a. One who knits or works up yarn or thread into a looped texture, for hosiery, etc.'

13 Hidalgo-Tenorio (2009) explores the role of conceptual metaphors in outlining 'Ireland' as seen through historical and modern conceptualisations. The evidence of a corpus of former Irish president Mary McAleese (President, 1997-2011) identifies caregiver as a source domain from which to describe a personified 'Ireland' in the metaphor: IRELAND IS A PERSON (A CAREGIVER).

14 The line of concordances include examples such as: 'A great resource with a wide range of hat patterns for both beginners and experienced knitters alike', 'For acrylic detractors, knitters and crocheters alike will be pleasantly surprised'. KWIC show that 'alike' has two main uses, illustrated in the examples, either to embrace different levels of knitters, or knitters with other craft work such as crochet.

15 The adverbs 'without' and 'alright' co-occur with 'knitter' so as to allude to essential requirements for this professionals -e.g. a wonderful technique that no knitter should be without, or as a colloquial expression to foreground the following information -e.g. 'alright you knitters, here are some patterns for you!, or as a means of agreement: 'She's an expert knitter, alright, but she's also in a hurry'.
} 
In contrast, there is only one use of 'knitter' in the corpus, within the dedication section, (KWIC 4). Here, 'knitter' co-occurs with '(life)story', ${ }^{16}$ 'hand', 'child', and 'loved'. We have to be tentative in the interpretation of this data as they only co-occur once. Nonetheless, this dedication, written by the author herself, is key so as to be aware of the structural constraints at play in the description of, not only the grandmother, but also the social worker, the mom, the foster parents, and all adults that evolve around Speranza and are in the position to help her integrating her life experience and to train her on how to use the 'needles' and 'loom' herself. In fact, and as an adult, she herself becomes a 'knitter' for her child. The case of visual parallelism between Speranza and her grandmother (Illustrations 6 and 7) highlights this personal growth.

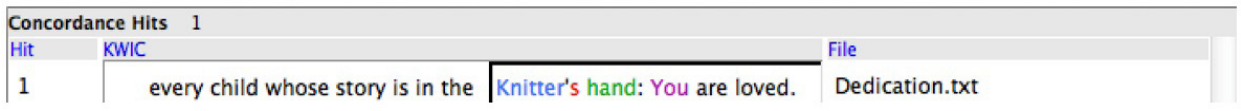

KWIC 4. 'Knitter' in SS (AntConc, Lawrence 2014).

By making use of the phrase 'knitter's hand', the active role of the Knitter is likewise drawn (almost) metonymically to a first position, by making explicit both intended referent (knitter) and referent (hand). If we analyse visually the hands of the knitter in the story, the grandmother, we see that these are the ones that hand-in the jumper to Speranza (p.23, Illustration 6) and cook a meal for her (p.14, Illustration 2). It is the grandmother who strengthens Speranza's hands so as to be able to continue the skill across future generations. We could analyse in this respect other adults' hands who are featured as helpers along the story, such as the social worker and the policeman (Illustration 3).

If we explore the word-form 'loved', which co-occurs with 'knitter', in the total corpus of SS via the search 'lov*', so as to be able to identify all word-forms, the corpus retrieves a total of nine hits (KWIC 5), which highlight the value of 'love' in the storyline and probably (AF) discourse.

In particular, it features Speranza as experiencer of 'love' to both parents, birth and foster/ adoptive parents, as well as phenomenon of the context who surrounds her and loves her. 'Loving' co-occurs with keywords that are markers of this love: 'belong', 'family', 'time', 'parents', 'knitter', and 'hand; though it also records the confusion and fears of Speranza when loving both parents at the same time, as well as her longing for a family ('daydream'). Finally, the last line of concordances (KWIC 5) points at the unconditional love of her forever family.

\begin{tabular}{|c|c|c|c|}
\hline \multicolumn{4}{|c|}{ Concordance Hits 9} \\
\hline \multicolumn{3}{|c|}{ Hit KWIC } & \multirow{10}{*}{$\begin{array}{l}\text { File } \\
\text { Author's Note.txt } \\
\text { Speranza's Sweater corpus.txt } \\
\text { Back Cover SS.txt } \\
\text { Speranza's Sweater corpus.txt } \\
\text { Speranza's Sweater corpus.txt } \\
\text { Speranza's Sweater corpus.txt } \\
\text { Speranza's Sweater corpus.txt } \\
\text { Dedication.txt } \\
\text { Speranza's Sweater corpus.txt }\end{array}$} \\
\hline 1 & ope of knowing they belong and are & loved. & \\
\hline 2 & didn't stop loving the other. She & loved both at the same time. One day & \\
\hline 3 & from her present, into a future of & love, family, and the true meaning of home. & \\
\hline 4 & And sometimes she daydreamed of a & loving family who would make her their new & \\
\hline 5 & ? Would her mom think she didn't & love her anymore? Would this mean she wouldn' & \\
\hline 6 & d her mom and dad sometimes. She & loved one set of parents and didn't & \\
\hline 7 & set of parents and didn't stop & loving the other. She loved both at the & \\
\hline 8 & in the Knitter's hand: You are & loved. To everyone who somehow feels connected & \\
\hline 9 & scary. Lying isn't okay, but we & love you no matter what. Telling us the & \\
\hline
\end{tabular}

KWIC 5. 'Lov*' in SS (AntConc, Lawrence 2014).

16 'Life story' was therefore chosen as target domain to specify the overarching metaphor in SS. 
In relation to the lexical nets that surround the word-form 'caregiver' in $i$ Web (Mark Davies) (Graph 3), these are linked to (i) kinship ('family', 'parent', 'member') either because caregivers are in close contact with them and require their help, ${ }^{17}$ or because kinship themselves act as caregivers; ${ }^{18}$ (ii) the people they provide help to and their characteristics ('patient', 'child', 'elderly', 'chronically', 'terminally', 'developmentally'); (iii) the care they provide ['care' (n. and v.), 'support' (n.), 'assist', 'accompany'] ${ }^{19}$ or receive/need ('support', 'assist') ${ }^{20}$ as well as their own role ('role', 'primary'); (iv) the actions or characteristics that are associated to their profession in relation to appointment, learning, and work ('refer', 'hire', 'designate', 'train', 'informal', 'emotionally', 'tirelessly'), and (v) the context they are part of ['medical', 'medically' (in relation to treatment, patients or professionals), 'professional' (referring to caregivers or other people around them), 'loved' (within the pattern 'your/their loved one/s')]. It is key to notice that caregivers, families and patients are commonly depicted as a network joining forces in favor of the patient, and so they frequently co-occur as in: 'I have met so many patients, families and caregivers who need simple but really important little things'. ${ }^{21}$

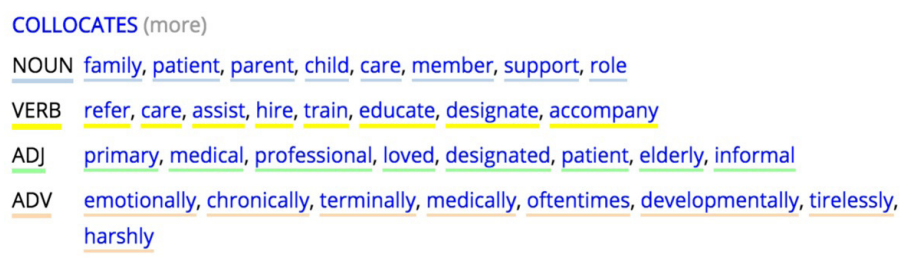

Graph 3. Caregiver's collocates (iWeb, Mark Davies).

The 'knitter' in the storyline is the grandmother. If we have a look at the line of concordances (KWIC 6 ) for 'grandma', 'knitter', and 'she' in SS, ${ }^{22}$ we notice that it cooccurs with the source domain 'sweater', which is understood as a 'gift', as well as the target domain 'story' and 'adoption'. Other keywords include 'time', 'new' and 'old', which temporally delineate the story, as well as 'hand', which highlight the agentive role of the

17 'Parents should seek a caregiver who is warm, caring, self-confident, attentive, and responsive to the children' ( $i$ Web, Mark Davies).

18 Following a patients discharge, family members often become caregivers, acting as the central support system for their loved one ( $i W e b$, Mark Davies).

19 'Focusing on early childhood literacy and support of parents and caregivers, two pilot programs are currently taking place in Austin at the St. John Branch' ( $\mathrm{WWeb}$, Mark Davies).

20 'Despite improvements in the treatment of CF (Cystic Fibrosis), physical and emotional support for patients and caregivers is a continuing need' ( $i$ Web, Mark Davies).

21 There are only four cases of 'harshly' with no defined pattern. In turn, 'oftentimes' alludes to common tendencies in caregivers' behaviour.

22 Cases of 'she' have been explored so as to identify only those which refer to 'grandma', deleting consequently those that did not match the selection criterion. 
grandmother, who 'make[s]' a new sweater, and takes ('took') the yarns for it. Her experience and related knowledge is further discussed in section (3.3.).

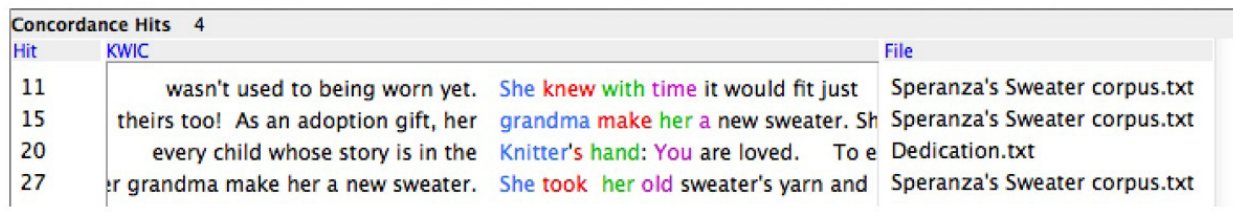

KWIC 6. 'Grandma'/'Knitter'/'she' in SS (AntConc, Lawrence 2014).

Even though the grandmother is not textually mentioned until the moment in which she knits sweater ${ }_{2}$ for Speranza (Illustration 6, page 23), we meet her earlier in the story (Illustration 2), around the centre of the narration. This visual presentation of the character exemplifies the interplay of visual and textual modes in picture books' storytelling.

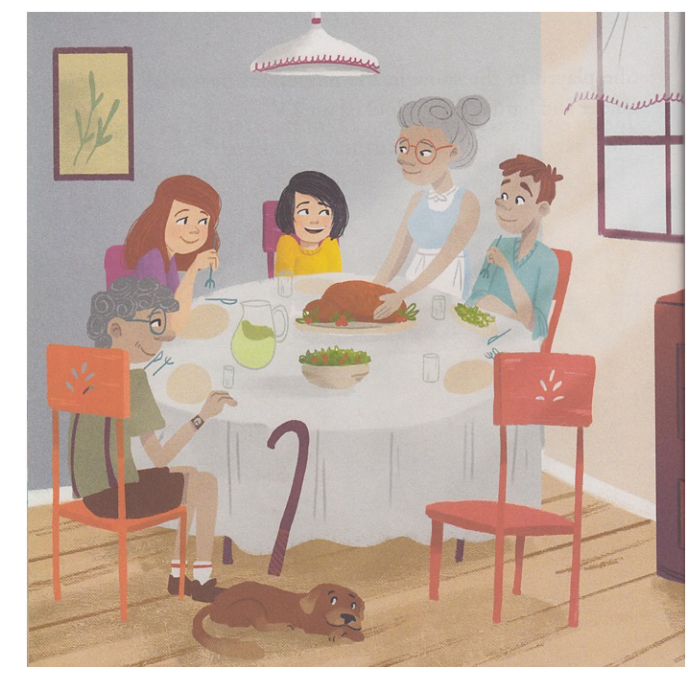

Illustration 2. Speranza at a family reunion .

(C) Marcy Pusey. Illustrated by Beatriz Mello (2018: 14)

The text that accompanies this illustration (11) alludes to a 'family reunion' which probably involved visiting the grandparents, and the pleasing time she had.

(11) "They went to a family reunion. She liked pretending they were her family. She rubbed her cheeks, sore from all the smiling." (Pusey 2018: 15)

Having a closer look at Illustration 2 we notice how the grandmother positions herself in between Speranza and Speranza's foster dad to serve the meal, interacting with the child, and placing her hands next to the food; the same hands with which she later knits sweater . $^{\text {. }}$ 
Although participants are in the intimacy of the grandparents' house, we can see the light coming through the window (maybe an open window due to the movement of the curtains) and illuminating the grandmother in a diagonal line, which joins both grandmother and granddaughter. The salad can be understood as a healthy eating choice, nourishing and taking care of Speranza, and we may find as well comfort in the culinary tradition across generations, which is here embodied in the figure of the grandmother. ${ }^{23}$ Participants, including the grandfather and the (foster) parents, are seated around a rounded table; whose shape can represent the equality of those seated at it, and also mirrors the rounded shape of the carpet (Illustration 6 and Illustration 7). The dog pet equally rests pleasingly next to the grandfather who we can identify due to his grey hair, glasses and walking stick. Speranza's Sweater adds to the pattern identified in Calvo-Maturana and Forceville (in press) in which grandparents play a major role in the child's life story, challenging the standard nuclear family, as evidenced in a selection of awarded and non-awarded picture books. Also in line with this research, we can argue that Speranza's Sweater is inclusive as for the depiction of family, range of age, and visualisation of physical disability.

It is the grandmother who is Speranza's helper, tailoring/mapping her experiences, enabling the child to continue her new path while at the same time celebrating her former self; and strengthening a sense of belonging. As mentioned in the introduction to this section, the key role of the grandmother is explicitly alluded in the author's opening dedication, in which the capitalised and thus graphologically foregrounded word 'Knitter' gives us the clue to understand the underlying metaphor in (Speranza's) story A (CHILD's) LIFE STORY IS A SWEATER and the essential role of adults who are in the position of delineating the child's experiences. The dedication therefore enhances the structural constraint 'It is handmade by a knitter', activating it in the transferring process (see section 3.3.). Table 2 presents the delineation of the domains 'knitter' and 'caregiver' following the exploration in the OED, iWeb and SS.

\begin{tabular}{|c|c|}
\hline Knitter & Caregiver \\
\hline $\mathrm{Ds}=<\mathrm{V}+\mathrm{S}>$ & $\mathrm{Dt}=<\mathrm{V}+\mathrm{S}>$ \\
\hline $\begin{array}{l}\text { Vs= 'ties', 'knots', 'stick', 'unites', 'joins', } \\
\text { 'knits', 'crochet', 'pattern', 'yarn', 'thread', } \\
\text { 'looped', 'sock', 'hosiery', 'expertise', } \\
\text { 'fairly', 'beginner', 'fellow', 'intermediate', } \\
\text { 'experienced', 'advanced', 'skilled', 'avid', } \\
\text { 'proudly', 'pride, 'wonderful', 'gift', 'hand', } \\
\text { 'busily', 'needle', 'spinner', 'loom', 'tight', } \\
\text { 'everywhere', 'nationwide', etc }\end{array}$ & $\begin{array}{l}\text { Vt= 'support', 'accomany', 'family', 'parent', } \\
\text { 'child', 'patient', 'elderly', 'care', 'member', } \\
\text { 'medical', 'professional', 'tirelessly', } \\
\text { 'chronically', 'primary', 'emotionally', } \\
\text { 'refer', 'hire', 'designate', 'train', etc } \\
\mathrm{St}= \\
(1 \mathrm{t})=\text { A caregiver provides support and care, as } \\
\text { well as company. [textual/visual] Sometimes } \\
\text { in turn, the caregiver is in need for that same } \\
\text { support. }\end{array}$ \\
\hline
\end{tabular}

continue next page

23 In a following spread, Speranza takes and saves food from her foster parents' fridge, concerned about lacking food to feed herself. She needs the reassurement of her foster parents to learn that there will always be enough food at hand and, more importantly: 'They still didn't make her leave.' (cf. parallelism with Gilman 2009 mentioned in the introduction section). 


\begin{tabular}{|c|c|}
\hline Knitter & Caregiver \\
\hline $\begin{array}{l}\mathrm{Ss}= \\
(1 \mathrm{~s})=\text { A person who knots, unites, or strongly } \\
\text { tights together. } \\
(2 \mathrm{~s})=\text { One who knits, stitches, or makes } \\
\text { crochet, creating patterns of yarn or thread } \\
\text { such as looped textures, and clothing like } \\
\text { socks. } \\
(3 \mathrm{~s})=\text { It is a skill that requires expertise. } \\
(4 \mathrm{~s})=\text { There are different degrees of expertise: } \\
\text { 'beginner', 'intermediate', 'experienced', } \\
\text { 'advanced', 'skilled', 'avid'. } \\
(6 \mathrm{~s})=\mathrm{It} \text { is a handmade craft, 'hand' } 24 \\
(7 \mathrm{~s})=\text { A knitter requires tools such as a needle, } \\
\text { a spinner or a loom. } \\
(8 \mathrm{~s})=\text { Some of the patterns are given as gifts. } \\
\text { Equally, knitters are normally given gifts } \\
\text { related to their work. } \\
(9 \mathrm{~s})=\text { They perform a worldwide practice. } \\
\text { (10s)= Knitters have a sense of collective and } \\
\text { inclusivity. }\end{array}$ & $\begin{array}{l}(2 t)=\text { She/he can be a family, a parent, a social } \\
\text { worker... [textual/visual] } \\
(3 t)=\text { A caregiver takes care of children, } \\
\text { patients, or the elderly; population who can } \\
\text { be in a vulnerable situation. [textual/visual] } \\
(4 t)=\text { She/he provides medical/professional } \\
\text { care. [textual/visual] } \\
(5 t)=\text { They work tirelessly to provide care and } \\
\text { well-being. } \\
(6 t)=\text { They take care of chronically ill } \\
\text { patients. } \\
(7 t)=\text { Caregivers can be primary or non- } \\
\text { primary. } \\
(8 t)=\text { Their work can be emotionally } \\
\text { demanding. [visual] } \\
(9 t)=\text { A caregiver can be hired for a position, } \\
\text { as well as trained. } \\
(10 t)=\text { Caregivers, families and patients are } \\
\text { a network working towards well-being. } \\
\text { [textual/visual] } \\
(11 t)=\text { Caregivers take care of our loved ones. } \\
\text { [textual/visual] }\end{array}$ \\
\hline
\end{tabular}

Table 2. 'Knitter' and 'caregiver' domains.

Here, the structural constraints in bold letters are the ones which are activated in the transferring process, while the others are downplayed and non-applicable in the restructuring of ad hoc caregiver, as understood in the particular context of the story.

The restructured $\mathrm{D}_{\mathrm{t}}$ or $\mathrm{D}_{\mathrm{t}}^{\mathrm{M}}$ in A CAREGIVER AS A KNITTER can thus be specified as:

$\left[1_{t}^{\mathrm{M}}\right]$ A caregiver provides support and care helping a child uniting/tightening together their life experiences.

$\left[2_{t}^{\mathrm{M}}\right]$ Caregivers work with their hands, and provide care and affection, accompanying the child.

$\left[3_{t}{ }^{M}\right]$ Caregivers require expertise, sometimes professional, sometimes as result of their age (as Speranza's grandmother).

$\left[4_{t}{ }^{\mathrm{M}}\right]$ Caregivers' actions result in a gift to the person in care, and it is a profession/an action to praise.

$\left[5_{t}{ }^{M}\right]$ Caregivers can form a collective, a support group, around the people in care.

24 'We love to work with our hands. We're knitters and makers, after all! In this example, we can see the cherished nature of hand-made crafting and the emphasis on hands. 


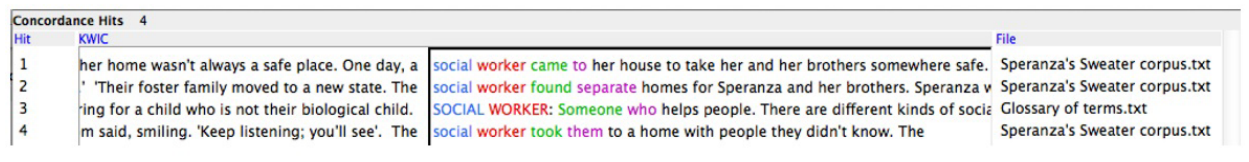

KWIC 7. 'Social worker' in SS (AntConc, Lawrence 2014).

There once was a little girl about your age. But her home wasn't always a safe place. One day, a social worker came to her house to take her and her brothers somewhere safe. Along with a few special items, she brought her favorite sweater."

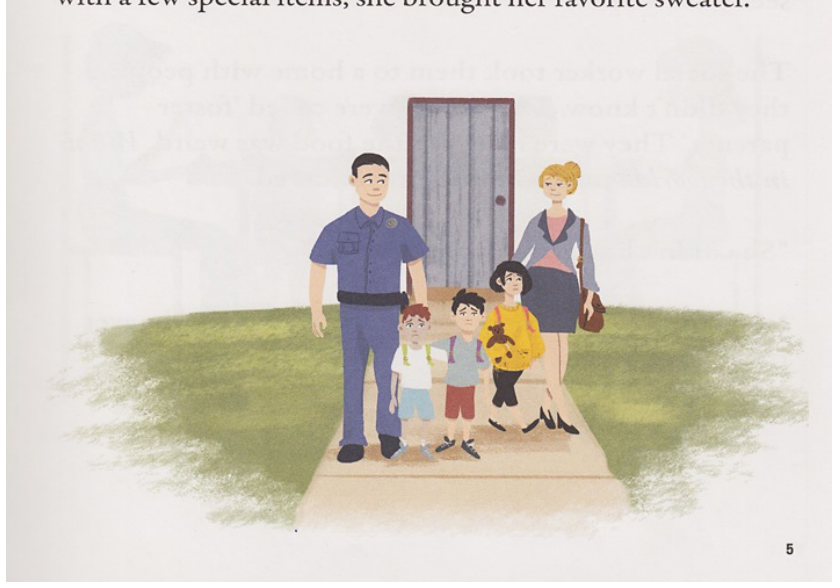

Illustration 3. Speranza leaves her home.

(C) Marcy Pusey. Illustrated by Beatriz Mello (2018: 5)

Even though the grandmother is literally and figuratively the 'knitter' in the storyline, we should likewise consider other figures who likewise fulfil the metaphorical role of the knitter for 'Speranza', such as the social worker, her mom, the foster and adoptive parents, or Speranza herself in relation to her two younger brothers (Illustration 1). A complete study in this sense would require exploring the KWIC for these word-forms as well as the related pronouns. As an example, the word-form 'social worker' in SS, co-occurs with keywords such as 'help' and 'safe', and is presented as an agentive figure: 'came', 'found', 'took', in protection of Speranza and her brothers whenever they were in a vulnerable situation.

\subsection{Belonging: A pattern of life experiences that fits}

This section explores the overarching metaphor in SS: A LIFE STORY (OF A CHILD IN FOSTER CARE OR ADOPTION) IS A SWEATER, which can be further subdivided into the more specific ones: SPERANZA'S PAST IS SWEATER ${ }_{1}$ and SPERANZA'S PAST, PRESENT AND FUTURE IS SWEATER $_{2}$. 
The sense for 'sweater' in the Oxford English Dictionary (OED) that applies to the story and its definition in our conceptual system finds its origin in the late $19^{\text {th }} \mathrm{C}$, early $20^{\text {th }} \mathrm{C}$ :

A woollen vest or jersey worn in rowing or other athletic exercise, originally (cf. a) ${ }^{25}$ in order to reduce one's weight; now commonly put on also before or after exercise to prevent taking cold. Hence a similar garment for general informal wear; a jumper or pullover.

Nonetheless, a comprehensive understanding of the metaphor in the story line requires an understanding of 'sweater' beyond the ready-made concept, and so reconfigured as an $\mathrm{ad}$ hoc concept. In fact, this is the origin of SSbt, narrated by Speranza, in answer to her son's question: "Mama, why do you keep this old sweater?" [...] "Looks kinda plain to me.”, who does not understand 'the meaning' of the sweater since at first glance it may seem 'old' or 'kinda plain'. ${ }^{26}$ We could argue that there are two ad hoc domains, two reconceptualisations of 'sweater' that are used so as to represent Speranza's life, linking her past with her present and future life, as well as her carers: the one which is worn-out now and accompanies Speranza along her childhood and the foster care experiences ( sweater $_{l}$ ), and a new one that her (adoptive) grandmother knits for Speranza ( sweater $_{2}$ ) and is described in the book with the following words:

As an adoption gift, her grandma made her a new sweater. She took her old sweater's yarn and some new yarn. Speranza picked the color. It was a little big and wasn't used to being worn yet. She knew with time it would fit just right. And it did (Pusey 2018: 23-24).

It is in Speranza's words and the illustrations that the source domains sweater $_{1}{ }^{M}$ and sweater ${ }_{2}{ }^{M}$ are ultimately built. They are thus multimodally construed, some features being conveyed, and thus emphasized, in both modes, textual and visual; others only specified in one of these semiotic modes.

Table 3 provides the delineation of 'sweater' as a ready-made concept following the OED, as well as the evidence of its collocates in $i$ Web (Graph 4), while Table 3 and Table 4 focus on the reconfiguration of sweater and sweater, as ad hoc concepts.

Results drawn by $i$ Web (Graph 4) in relation to 'sweater's collocates allow us to define its semantic preference around the lexical sets of clothing ('jacket', 'shirt', 'dress', 'jeans', 'cashmere', 'coat'), period of time ('Christmas'), actions relating with: putting clothes items on ('wear', 'dress'; creating them: 'knit'), classifying them ('pack', 'wrap'), or cleaning them ('wash'). Adjectives and adverbs likewise qualify 'sweater' and its related actions in terms of colour ('black', 'light', 'white', 'red', 'blue', 'brightly'), appearance ('ugly', 'beautifully'), the comfort they bring ('cozy', 'warm', 'cuddly'), or ways of wearing it ('underneath', 'casually', 'neatly', 'loosely', 'effortlessly').

25 "a. plural. Clothes in which a horse or a man in training is exercised, to produce profuse sweating" [early and mid 19th C].

26 This is likewise the case for the reader and viewer, who when first encountering the sweater on the inner cover, dedication page, or the introductory page (p.4), may understand the depicted sweater as a random one, matching her/his conceptual system. This enables us to identify the drawn item as a 'sweater'. 


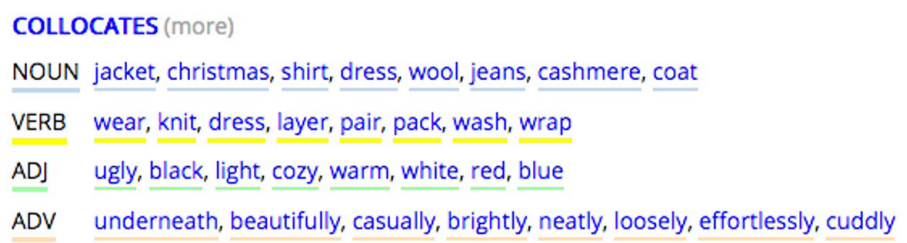

Graph 4. Sweater's collocates (iWeb, Mark Davies).

As for the source domain, it has been phrased as 'life story', ${ }^{27}$ due to the following aspects related to its occurrence in SS (KWIC 8) as well as the nature of this picture book: (i) the total number of occurrences of the word-form 'story' in SS, a total of six times (ii) its specific occurrence in the back cover, dedication page, and author's note, which seem to address the adult reader while at the same time specifying the essence of the book, (iii) its occurrence within adult Speranza' speech, in the opening of the book, just before narrating her 'story', and (iv) the value of 'life story' books in adoption and foster care experiences, as specified by social worker Rees (2009), which present questions and concerns that in Speranza's Sweater are creatively addressed in the shape of a picture book.

In essence, life story books should provide answers to the many questions children are likely to have - but may be reluctant to ask - about their early life experiences, prior to their adoptions. The what happened, when and why questions (Rees 2009: 11).

The format of a picture book does not only offer a space for Speranza's life story book, which is 'unique to her' (Pusey 2018: 27), but to any child who may 'relate to her feelings' (Pusey 2018: 27), creating thus a context to learn about emotions and identity.

If we notice $K W I C 8$, the line of concordances for 'story' includes keywords such as 'weave', 'threads'/'strands', 'past' vs. 'present', 'knitter', 'warm' or 'heart', as the back cover and dedication page specifically address the running metaphor, offering the vehicles that signpost the transferring features from source into target.

\begin{tabular}{|c|c|c|}
\hline \multicolumn{3}{|c|}{ Concordance Hits 6} \\
\hline Hit & KWIC & \multirow{2}{*}{$\begin{array}{l}\text { File } \\
\text { Back Cover SS.tx }\end{array}$} \\
\hline 1 & , Speranza must weave together a new story, bringing threads from her past and strands from her present & \\
\hline 3 & Author's Note Not every child's story is the same as Speranza's. Some children stay with & Author's Note.txt \\
\hline 4 & challenging system. While Speranza's story is unique to her, every child will relate to her & Author's Note.txt \\
\hline 5 & e who somehow feels connected to the story! May the illustrations inspire and warm your heart. & Dedication.txt \\
\hline
\end{tabular}

KWIC 8. 'Story' in SS (AntConc by Lawrence 2014).

Considering the collocates of 'story' in $i W e b$, these are associated to the semantic fields of the own inner nature of the story ('love', 'horror', 'ghost', 'bible'); actions mainly linked to: communicating that story to an addressee/s ('tell', 'recount', 'retell', 'share', 'illustrate'),

27 The OED defines 'life story as': 'the story of a person's life, a biography'. 
receiving the message ('hear'), or its structure ('unfold', 'weave'); its evaluation which is mainly linked to emotional or intellectual engagement ('short', 'true', 'related'-notice here the emphasis on connections- 'interesting', 'funny', 'compelling', 'sad' or 'fascinating'); and ways of communicating ('aloud', 'read-aloud', 'short'28), presenting its structure or creating it ('chronologically' -notice here the attention to time in narration which is below discussed in relation to the 'inverted story', 'masterfully' ${ }^{29}$ ) or affecting the addressee ('compellingly'- notice here its frequency as it is also used within the collocates' span as adjective), as well as further defining the nature of the story ('darkly' ${ }^{30}$ or 'thematically').

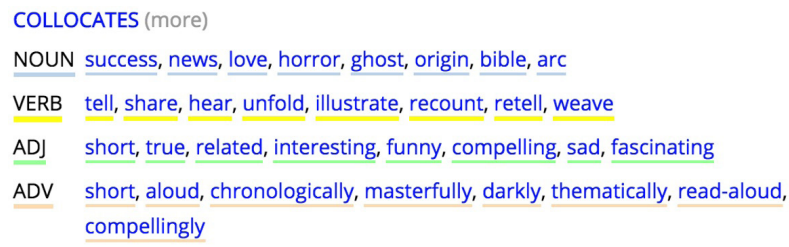

Graph 5. Story's collocates (iWeb, Mark Davies). 9770362 Frequency tokens.

Amongst the co-occurrences of 'story' in $i W e b$ (Graph 5), there is a keyword: 'weave' that links to the running metaphor in SS and suggests that, despite being exploited differently in SS, this metaphor is already part of the use of language. Case (12) is extracted from iWeb as a means of example. Here, we notice how 'woven' co-occurs with 'story' in the metaphor A STORY IS A TAPESTRY.

(12) Tim has masterfully woven a simple love story, intertwining the joy of new love, the challenge of enduring love, the hope of renewed love, and the joy of lasing love into a beautiful and complex tapestry. [waterbrookmultnomah.com] (emphasis added).

Tables 3 and 4 gather the outline of source and target domains in A LIFE STORY (OF A CHILD IN FOSTER CARE OR ADOPTION) IS A SWEATER, including the necessary ad hoc restructuring of sweater $_{1}$ and sweater, . $_{\text {. }}$.

When writing the running metaphor in the book, the word 'child' was included so as to acknowledge the role of the adult or care-giver who is in charge of or in the position of helping a vulnerable person, a person in need, a child by means of joining/integrating their life experiences into a beautiful pattern while at the same time providing comfort and well-being that can embrace and hold together their experiences, providing a continuation.

28 The adverb 'short' mainly refers at ways in which the story is going to be summarized and forms part of the phrase 'in short', e.g. 'In short, my Cinderella story has not been without villains, naysayers, and scary times' (iWeb).

29 We find cases in which 'masterfully' co-occurs with the keyword 'weaves' such as: 'Ken Follett masterfully weaves these stories through the political turmoil of 12th century England' (iWeb).

30 The adverb 'darkly' mainly defines the adjectives alluding to the story's inner nature, such as: 'Harry Chapin's " Taxi " is a darkly romantic ghost story'. 


\begin{tabular}{|c|c|}
\hline Sweater & (Life) story \\
\hline $\mathrm{Ds}=<\mathrm{V}, \mathrm{S}>$ & $\mathrm{S}>$ \\
\hline $\begin{array}{l}\text { Vs= 'sweater', 'woollen', 'cashmere', } \\
\text { ‘jersey', 'garment', 'jumper', 'pullover', } \\
\text { 'wear', 'dress' (v.), 'layer', 'underneath', } \\
\text { 'pair', 'pack', 'wash', 'knit', 'exercise', } \\
\text { 'athletic', 'casual', 'warmth', 'yarn', } \\
\text { 'knitting', 'jacket', 'shirt', 'dress' (n.), 'jeans', } \\
\text { 'coat', 'black', 'red', 'white', 'brightly', } \\
\text { 'ugly', 'beautifully', 'cozy', 'light', 'warm', } \\
\text { 'casually', 'Christmas', 'cuddly', etc. }\end{array}$ & $\begin{array}{l}\text { Vt= 'life', 'story', 'person', 'biography', } \\
\text { 'success', 'news', 'love', 'horror', 'ghost', } \\
\text { 'origin', 'bible', 'arc', 'tell', 'share', } \\
\text { 'hear', 'unfold', 'illustrate', 'recount', } \\
\text { 'retell', 'weave', 'short', 'true', 'related', } \\
\text { 'interesting', 'funny', 'compelling', 'sad', } \\
\text { 'fascinating', etc. }\end{array}$ \\
\hline $\begin{array}{l}\mathrm{Ss}= \\
(1 \mathrm{~s})=\mathrm{It} \text { is made of wool of different types }\end{array}$ & $\begin{array}{l}(1 \mathrm{t})=\text { It narrates a person's life, his/her } \\
\text { biography. }\end{array}$ \\
\hline $\begin{array}{l}\text { such as cashmere. } \\
(2 \mathrm{~s})=\mathrm{It} \text { is made of }\end{array}$ & $\begin{array}{l}(2 t)=\text { Someone can tell/recount, share, hear or } \\
\text { illustrate a story, or alternatively retell it. }\end{array}$ \\
\hline $\begin{array}{l}\text { prepared for knitting [see OED's entry for } \\
\text { ‘yarn']. [textual/visual] }\end{array}$ & $\begin{array}{l}(3 \mathrm{t})=\text { Life, events, memories can unfold into } \\
\text { stories. }\end{array}$ \\
\hline $\begin{array}{l}(3 \mathrm{~s})=\text { It is knitted or woven, sometimes } \\
\text { loosely. }\end{array}$ & $\begin{array}{l}(4 t)=\text { There are well-known stories such as } \\
\text { the 'bible story'. }\end{array}$ \\
\hline $\begin{array}{l}\text { (3s)= It is also referred to as 'jersey', } \\
\text { 'garment' [former terms], 'jumper', or } \\
\text { 'pullover'. }\end{array}$ & $\begin{array}{l}(5 t)=\text { There are 'love', 'horror', and 'ghost' } \\
\text { stories. }\end{array}$ \\
\hline $\begin{array}{l}(4 s)=\text { It is sometimes worn during exercise, } \\
\text { such as athletic exercise. }\end{array}$ & $\begin{array}{l}(6 t)=\text { Stories can be of 'success'. } \\
(7 t)=\text { It is possible to 'weave' a story. }\end{array}$ \\
\hline $\begin{array}{l}(5 \mathrm{~s})=\text { It can sometimes be worn casually or } \\
\text { result in an effortlessly stylish look. }\end{array}$ & $\begin{array}{l}\text { tory can be displayed as a story arc } \\
\text { orytelling media. }\end{array}$ \\
\hline $\begin{array}{l}(6 s)=\text { It provides warmth and shelter from } \\
\text { cold conditions, as well as general comfort: }\end{array}$ & $\begin{array}{l}(9 t)=\text { The origin story sets the background to } \\
\text { later story events. }\end{array}$ \\
\hline 'cozy', 'cuddly'. [te & re sometimes presented in \\
\hline $\begin{array}{l}(7 \mathrm{~s})=\text { It might be paired with other clothes } \\
\text { items such as: a jacket, a shirt, a dress, a pair } \\
\text { of jeans, or a coat, amongst others; or may }\end{array}$ & $\begin{array}{l}(11 t)=\text { There is a literary genre known as short } \\
\text { story. }\end{array}$ \\
\hline $\begin{array}{l}\text { be layered over them or worn underneath. } \\
\text { [visual] }\end{array}$ & $\begin{array}{l}(12 \mathrm{t})=\text { Stories are sometimes described as } \\
\text { 'true', on other occasions we refer to a true }\end{array}$ \\
\hline$(8 s)=$ You can wrap in a sweater. & aspect of the story such as the true interest, \\
\hline $\begin{array}{l}(9 s)=\text { It is a clothes item to pack in a suitcase. } \\
\text { It can be folded neatly. }\end{array}$ & $\begin{array}{l}\text { villain, origin or hero. } \\
(13 \mathrm{t})=\text { Stories are usually connected to others. }\end{array}$ \\
\hline $\begin{array}{l}(10 \mathrm{~s})=\text { It can be washed and may require } \\
\text { specific instructions. }\end{array}$ & $\begin{array}{l}(14 t)=\text { Stories can engage the addressee } \\
\text { emotionally or intellectually. }\end{array}$ \\
\hline $\begin{array}{l}(11 \mathrm{~s})=\text { They may be of different single or } \\
\text { combined colours, including black, white } \\
\text { or red-sometimes brightly coloured, and are } \\
\text { equally worn in combination with clothes } \\
\text { items of various colours. [visual] }\end{array}$ & $\begin{array}{l}(15 t)=\text { Stories are usually presented in relation } \\
\text { to a certain chronological structure. }\end{array}$ \\
\hline
\end{tabular}

continue next page 


\begin{tabular}{|l|l|}
\hline Sweater & (Life) story \\
\hline $\begin{array}{l}\text { (12s)= They may be characterised in terms } \\
\text { of their appearance (e.g. ugly, beautifully } \\
\text { crafted), their weigh (e.g. light), or the } \\
\text { comfort they provide (e.g. cozy, warm). }\end{array}$ & $\begin{array}{l}(16 \mathrm{t})=\text { Stories may be communicated aloud. } \\
(17 \mathrm{t})=\text { Stories can involve a certain degree of } \\
\text { mastering. }\end{array}$ \\
$\begin{array}{l}\text { with cold weather, but Christmas period is } \\
\text { specially highlighted in relation to sweaters, } \\
\text { both with a positive [Nothing says Christmas }\end{array}$ & \\
like a cozy sweater and bright red lip! (iWeb)] & \\
and a negative connotation [Always be on & \\
the lookout for a good ironic Christmas & \\
sweater. Ugly sweater parties have been all \\
the rage the past couple of years (iWeb).], or \\
in relation to Christmas related designs or \\
graphics. [visual]
\end{tabular}

Table 3. 'Sweater' and 'life story' domains.

The need to activate (6s) is highlighted in the illustrator's dedication: 'To everyone who somehow feels connected to this story! May the illustrations inspire and warm your heart' (Pusey 2018, emphasis added). The word 'warm' highlights one key function of the 'sweater', which is here metaphorically attributed to the book story and illustrations. In fact, the book is entitled Speranza's Sweater; a sweater/a story that is lent to any reader to warm up. Moreover, 'warm' co-occurs with the word 'heart' that metonymically points to 'everyone who somehow feels connected to this story' and foregrounds the emotional value and comfort of identifying yourself or other selves in the storyline. As we can see, and following Romero and Soria (2005b), the metonymy here is a mandatory primary pragmatic process resulting from an unarticulated constituent, i.e. the intended referent, as can be seen in the square brackets: 'may the illustration inspire and warm [everyone who somehow feels connected to this story's] heart'. Here, the deictic possessive article 'your' anaphorically points at the intended referent, explicitly mentioned in the previous sentence, as well as exophorically to the reader.

Outlining the ad hoc source domains sweater ${ }_{1}$ and sweater ${ }_{2}$ (Table 4) demands both a textual and visual analysis. In these tables, vocabulary in italics signpost the words that are literally taken from the text and qualify either of these domains. In relation to the textual analysis, KWIC 9 shows the co-occurrences of sweater ${ }_{1}$ and sweater $_{2}$, which are used in the reconstruction of the ad hoc domains in Table 4. In here, even though the same word ('sweater') is used to allude to both of them, the line of concordances 2,5,9, and 10 refer to sweater ${ }_{1}$ whereas 3,6,7, and 8 allude to sweater $_{2}$. As for lines 1 and 4, which are part of the book's title Speranza's Sweater, it may well be that they likewise allude to sweater, as the headline in the book cover is delineated with yarns that spread from it. 


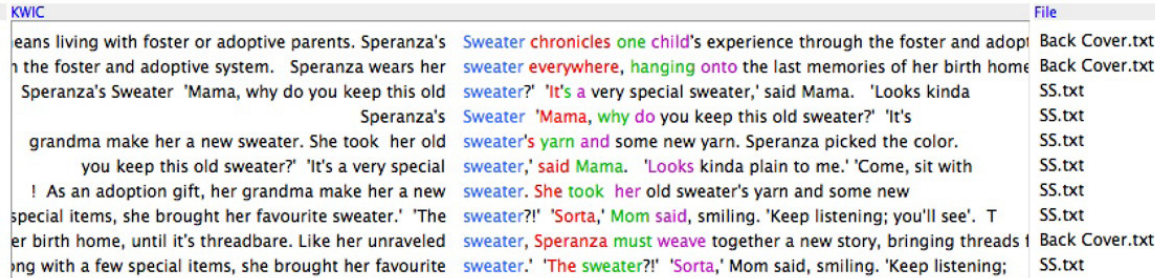

KWIC 9. 'Sweater' in SS (AntConc, Lawrence 2014).

Together with the outlined terms and structural constraints in Ds in Table 3, the following features are applicable to sweater ${ }_{1}{ }^{M}$ and sweater $_{2}{ }^{M}$ as construed along the book (Table 4).

\begin{tabular}{|c|c|}
\hline SWEATER $_{1}{ }^{M}$ & SWEATER $_{2}{ }^{M}$ \\
\hline $\begin{array}{l}\text { Ds =<V, S }> \\
\text { Vs= 'knitter', 'old', 'favourite', 'identity', } \\
\text { 'Speranza's', 'worn out', 'yarn', 'kinda plain', } \\
\text { 'birthmother', 'home', 'kept', 'adoption } \\
\text { ceremony', 'foster care experiences', 'new } \\
\text { birth certificate', 'yellow', 'unravelled', } \\
\text { 'threadbare', story, 'identity', etc. } \\
\text { Ss= } \\
(1 \mathrm{~s})=\text { We don't know if it is handmade by a } \\
\text { knitter. } \\
(2 \mathrm{~s})=\text { It is old [confront sweater }{ }_{2} \text { here]. } \\
\text { [textual/visual] } \\
\text { (3s)=It chronicles Speranza's experiences in } \\
\text { foster care and adoption. [textual/visual] } \\
\text { (4s)=It is Speranza's favourite sweater. The } \\
\text { one she decided to take with her when she left } \\
\text { her birthmother's home, together with a few } \\
\text { other } \text { special items [textual and visual], such } \\
\text { as a teddy bear [textual/visual] } \\
\text { (5s)= Speranza identifies herself with this } \\
\text { jumper [textual and visual] } \\
\text { (6s)= Speranza wears it everywhere. [textual/ } \\
\text { visual] } \\
\text { (7s)= It is kept by its owner, worn indoors and } \\
\text { outdoors, or carried with Speranza, on a daily } \\
\text { basis, as well as in turning life moments such } \\
\text { as spending quality time at the beach with } \\
\text { the foster parents or an adoption ceremony } \\
\text { in which Speranza is given a new birth } \\
\text { certificate [visual] }\end{array}$ & 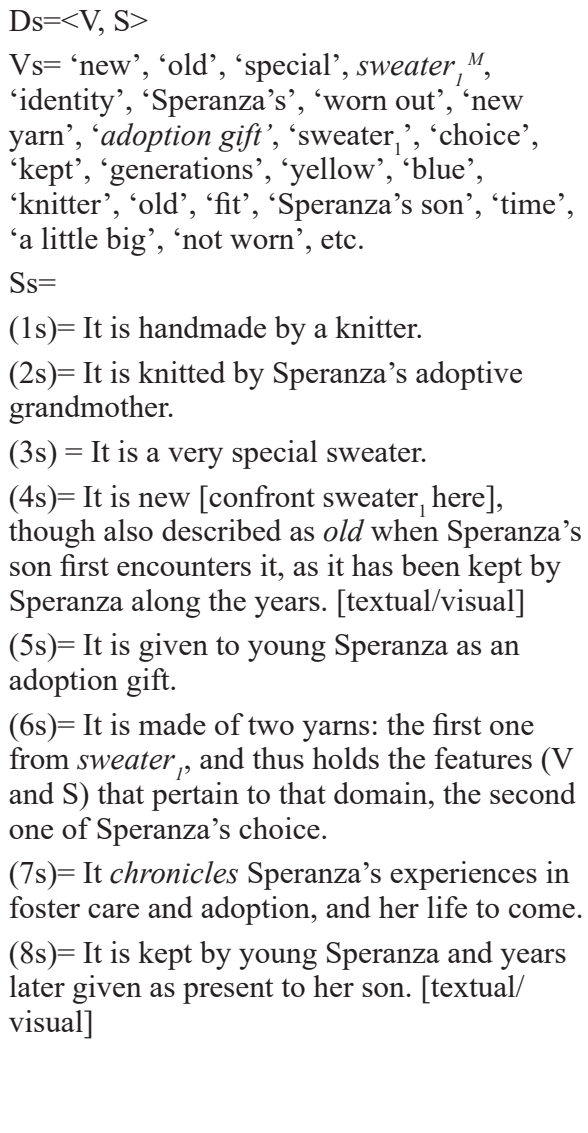 \\
\hline
\end{tabular}




\begin{tabular}{|l|l|}
\hline SWEATER $_{1}{ }^{M}$ & SWEATER $_{2}{ }^{M}$ \\
\hline $\begin{array}{l}\text { (8s) }=\text { It is physically unravelled and } \\
\text { threadbare due to passing time and use. }\end{array}$ & $(9 \mathrm{~s})=$ It is made of yellow (old yarn) and blue \\
[textual/visual] & $($ new yarn $)$ wool. [textual/visual] \\
$(9 \mathrm{~s})=$ Yarn is lost as time passes [visual] & her grandmother made it for her. \\
$(10 \mathrm{~s})=$ It is made of yellow wool. [textual/ & $(11 \mathrm{~s})=$ It fits Speranza's son. [textual/visual] \\
visual] & \\
$\begin{array}{l}(11 \mathrm{~s})=\text { Speranza's story is about } \text { sweater }_{1} \\
\text { [textual and visual] } \\
(12 \mathrm{~s})=\text { It is a visual metonymy of Speranza's } \\
\text { birth home. }\end{array}$ & \\
\hline
\end{tabular}

Table 4. Ad hoc source domains: sweater ${ }_{1}^{M}$ and sweater $_{2}{ }^{M}$.

Although in this picture book the textual and visual modes are not physically merged, in the sense that the text and visual elements occupy different sections - even if they maybe part of the same page, we can say that they are richly merged in terms of meaning and their integration plays a major role in the narration of the story. Table 5 offers a description and analysis of the extralinguistic elements at play in the framing of sweater as revealed in the illustrations, drawing on visual rhetorical devices as well as features of interpersonal and textual visual representation (Kress and Van Leeuwen [1996] 2006 and Moya Guijarro 2014). The column on the right-hand side shows the vocabulary and structural constraints informed through the visual analysis. As can be seen in Table 5, sweater ${ }_{1}$ is visually represented throughout the storyline, even if not specified textually. ${ }^{31}$

\begin{tabular}{|l|l|l|}
\hline Pages & $\begin{array}{l}\text { Description and analysis. Reference to visual rhetorical } \\
\text { devices and elements of interpersonal and textual visual } \\
\text { representation. }\end{array}$ & $\begin{array}{l}\text { Vocabulary and } \\
\text { Structural constraints } \\
\text { included in the } \\
\text { specification of the } \\
\text { domain } \text { sweater }_{1}\end{array}$ \\
\hline $\begin{array}{l}\text { Front } \\
\text { cover }\end{array}$ & $\begin{array}{l}\text { Speranza is worried, and stares at the loose yarn with } \\
\text { concern. She might be loosing some memories of her } \\
\text { home and birthmother. The title lettering thus rhymes with } \\
\text { the yarn yellow colour. Sweater gains prominence as it is } \\
\text { part of the front cover and reason for the main title. }\end{array}$ & $\begin{array}{l}\text { Prominence of } \\
\text { sweater }_{1} \\
\text { Speranza's story is } \\
\text { about } \text { sweater }_{1}\end{array}$ \\
\hline
\end{tabular}

31 On other occasions, we find characters who repeat their outfit through several scenes across time (e.g. Speranza's brothers' clothing), though their look is neither textually or visually foregrounded and thus does not seem to provide an added layer of meaning to the interpretation of the story, other than pictorically identifying the characters. 


\begin{tabular}{|c|c|c|}
\hline Pages & $\begin{array}{l}\text { Description and analysis. Reference to visual rhetorical } \\
\text { devices and elements of interpersonal and textual visual } \\
\text { representation. }\end{array}$ & $\begin{array}{l}\text { Vocabulary and } \\
\text { Structural constraints } \\
\text { included in the } \\
\text { specification of the } \\
\text { domain } \text { sweater }_{1}\end{array}$ \\
\hline $\begin{array}{l}\text { Inner } \\
\text { cover }\end{array}$ & $\begin{array}{l}\text { We meet Speranza for the first time in the narrative. The } \\
\text { character smiles at the reader with demand look, drawing } \\
\text { the reader in. There is a visual parallelism between this } \\
\text { illustration and the one in author's note, which also } \\
\text { features Speranza engaging the reader but with the } \\
\text { clothing she wears on her adoption day (p.27). Moreover, } \\
\text { both depictions of Speranza seem to act as a mirror as } \\
\text { they are facing each other, wrapping up the beginning and } \\
\text { end of the storyline. }\end{array}$ & Identity \\
\hline p. 5 & $\begin{array}{l}\text { Speranza leaves her birthmother's home in the company } \\
\text { of her brothers, a policeman and a social worker, to } \\
\text { whom she stares with sadness, while her two brothers } \\
\text { look at us in a demand look. }{ }^{32} \text { The door in the distance } \\
\text { metonymically represents Speranza's home, which is } \\
\text { blurred in this way. No further information is unveiled to } \\
\text { the viewer. }\end{array}$ & $\begin{array}{l}\text { Very special item, } \\
\text { compared to her teddy. } \\
\text { Worn outdoors, } \\
\text { Specially significant } \\
\text { moments }\end{array}$ \\
\hline p. 7 & $\begin{array}{l}\text { Speranza has a first meal with her foster parents and her } \\
\text { brothers. Speranza, wearing sweater }{ }_{l} \text { is at the centre and } \\
\text { thus foregrounded. The foster parents are on both sides } \\
\text { embracing the children, who look at the viewer in demand } \\
\text { look likewise showing their vulnerabily on their first day } \\
\text { with a new family. }\end{array}$ & $\begin{array}{l}\text { Worn indoors, } \\
\text { Specially significant } \\
\text { moments: first night } \\
\text { and meal with their } \\
\text { foster parents. }\end{array}$ \\
\hline p. $8-9$ & $\begin{array}{l}\text { Speranza wears sweater }{ }_{l} \text { when her birthmother visits } \\
\text { her at her foster parents'. The physical intimacy shows } \\
\text { the connection of mother and child, together with other } \\
\text { physical and outfit similarities, such as clothing and } \\
\text { haircut, that can point at Speranza having her mother as } \\
\text { role model. Here, Speranza's mother is wearing a jumper } \\
\text { which is likewise worn out. Its colour is meaningful in the } \\
\text { construction of the visual parallelism in Illustration } 4 \text { and } \\
\text { Illustration } 7 \text { as explained below. }\end{array}$ & $\begin{array}{l}\text { Worn indoors, Turning } \\
\text { life moments }\end{array}$ \\
\hline
\end{tabular}

continue next page

32 Speranza's second parental figure is never depicted in the story. Though mentioned twice in the narrative: 'Sometimes she missed her parents, even if they had fought a lot' (Pusey 2018: 11), 'She still missed her mom and dad sometimes. She loved one set of parents and didn't stop loving the other. She loved both at the same time' (Pusey 2018: 18), he does not take part as an agentive figure. We neither see if Speranza has a partner in her life with her son. 


\begin{tabular}{|c|c|c|}
\hline Pages & $\begin{array}{l}\text { Description and analysis. Reference to visual rhetorical } \\
\text { devices and elements of interpersonal and textual visual } \\
\text { representation. }\end{array}$ & $\begin{array}{l}\text { Vocabulary and } \\
\text { Structural constraints } \\
\text { included in the } \\
\text { specification of the } \\
\text { domain } \text { sweater }_{1}\end{array}$ \\
\hline p.10-11 & See Illustration 1, and related analysis (3.1.) & $\begin{array}{l}\text { Worn indoors, } \\
\text { Specially significant } \\
\text { moments } \\
\text { Yarn grows apart as } \\
\text { precious experiences } \\
\text { are lost. } \\
\text { 'Threadbare' } \\
\text { 'Unravel' }\end{array}$ \\
\hline p. 12 & $\begin{array}{l}\text { Speranza enjoys at the beach with her foster family } \\
\text { (Illustration 5). She wears a swimsuit but sweater }{ }_{1} \text { rests } \\
\text { on the sand next to her; her foster care mother adjusts } \\
\text { the flag of the sandcastle they have built together. Her } \\
\text { foster dad and little foster sister lie on a deckchair in the } \\
\text { background. Clothing again draws similarities across } \\
\text { participants, all of them wearing polka-dots swimsuits. }\end{array}$ & $\begin{array}{l}\text { Quality time } \\
\text { Continuation of } \\
\text { sweater }{ }_{1} \text { [visual } \\
\text { intratextuality, } \\
\text { Calvo-Maturana and } \\
\text { Forceville in press] } \\
\text { New experiences } \\
\text { shared with her new } \\
\text { family. }\end{array}$ \\
\hline p. 13 & $\begin{array}{l}\text { Speranza, wearing } \text { sweater }_{l} \text { enjoys herself in the } \\
\text { mountains building a snowman. }\end{array}$ & $\begin{array}{l}\text { Quality time } \\
\text { New experiences }\end{array}$ \\
\hline p. 14 & $\begin{array}{l}\text { Speranza, wearing sweater } \text { meets her foster grandparents } \\
\text { at a family reunion. Grandparents, parents and Speranza } \\
\text { gather around a round table to enjoy a meal. The } \\
\text { grandmother figure is foregrounded by standing up while } \\
\text { serving the meal as well as interacting with Speranza. The } \\
\text { visual is then an anticipation of the key role played by the } \\
\text { grandmother. }\end{array}$ & $\begin{array}{l}\text { Quality time } \\
\text { New experiences } \\
\text { shared with her new } \\
\text { family. }\end{array}$ \\
\hline p.15 & $\begin{array}{l}\text { Speranza, wearing sweater }, \text { and her brothers play at her } \\
\text { brothers' foster parents home. }\end{array}$ & $\begin{array}{l}\text { Quality time } \\
\text { New experiences } \\
\text { shared with her } \\
\text { brothers }\end{array}$ \\
\hline p.16 & $\begin{array}{l}\text { Speranza, wearing sweater }{ }_{l} \text {, seats on the armchair around } \\
\text { her foster parents, who comfort her while educating } \\
\text { on the value of telling the truth. Physical intimacy of } \\
\text { the three participants show their connection, despite } \\
\text { Speranza's worried expression. Text says: 'They didn't } \\
\text { make her leave' }\end{array}$ & $\begin{array}{l}\text { Adjusting to her new } \\
\text { home and life situation }\end{array}$ \\
\hline p. 17 & $\begin{array}{l}\text { Speranza, wearing sweater, }{ }_{r} \text {, secretly takes food from the } \\
\text { fridge. Text says: 'They still didn't make her leave' }\end{array}$ & $\begin{array}{l}\text { Adjusting to her new } \\
\text { home and life situation }\end{array}$ \\
\hline
\end{tabular}

continue next page 


\begin{tabular}{|c|c|c|}
\hline Pages & $\begin{array}{l}\text { Description and analysis. Reference to visual rhetorical } \\
\text { devices and elements of interpersonal and textual visual } \\
\text { representation. }\end{array}$ & $\begin{array}{l}\text { Vocabulary and } \\
\text { Structural constraints } \\
\text { included in the } \\
\text { specification of the } \\
\text { domain sweater }\end{array}$ \\
\hline p.18-19 & $\begin{array}{l}\text { Speranza, wearing } \text { sweater }_{l} \text {, and her foster mother are } \\
\text { kneeling and praying, probably before bedtime. The yarn } \\
\text { significantly grows metres apart. }\end{array}$ & $\begin{array}{l}\text { Quality time } \\
\text { New experiences } \\
\text { shared with her foster } \\
\text { mother }\end{array}$ \\
\hline p. 20 & $\begin{array}{l}\text { Speranza at her adoption ceremony. Sweater } \text { is the only } \\
\text { item that lays at the square table centering the scene. } \\
\text { She is seated next to it and her foster parents are in front } \\
\text { of her, in mirror fashion. There are benches on both } \\
\text { sides, with Speranza's grandparents, just behind her, } \\
\text { holding her back, and her little foster sister, carried by the } \\
\text { grandmother. On those of the left hand side, sheltering } \\
\text { the foster parents, we can see a woman who might be the } \\
\text { social worker (cf. p.5). Judge Cordoza centres the scene } \\
\text { at a different table. She is about to declare the adoption } \\
\text { and legal custody as she hits the gavel. It is only visually } \\
\text { that we learn that Judge Cordoza is female. These are } \\
\text { decisions taken by the illustrator and part of the additional } \\
\text { information that is only pictorially conveyed. }\end{array}$ & $\begin{array}{l}\text { Specially significant } \\
\text { moments } \\
\text { Adoption ceremony } \\
\text { Shared experiences } \\
\text { with family }\end{array}$ \\
\hline p. 22 & $\begin{array}{l}\text { Speranza and her new forever family walk together } \\
\text { [probably upon leaving the court, though there is no visual } \\
\text { context about location]. Speranza is at the centre, her two } \\
\text { brothers on both sides. The three of them are connected. } \\
\text { Walking just a bit behind them and on both sides we can } \\
\text { see Speranza's parents, foregrounded on the right-hand } \\
\text { side, and Speranza's brothers' parents on the left-hand } \\
\text { side. Speranza wears sweater }{ }_{1} \text {, wrapped up around her } \\
\text { waist. This is the last scene in which we see sweater }{ }_{l} \text {. }\end{array}$ & $\begin{array}{l}\text { Specially significant } \\
\text { moments } \\
\text { Adoption ceremony } \\
\text { Shared experiences } \\
\text { with family }\end{array}$ \\
\hline
\end{tabular}

Table 5. Visual representation of sweater. 


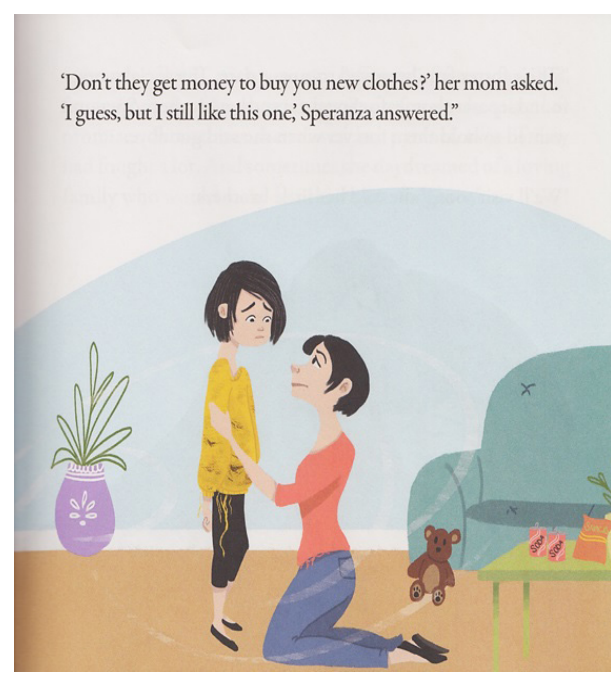

Illustration 4. Speranza and her mother at the foster parents' home. We see again the teddy bear in a case of intratextuality (pp.59) which foregrounds both, the teddy itself and the jumper as special items. Speranza's birthmother sweater is also worn out, in her case, as the text reinforces, probably due to lack of income.

(C) Marcy Pusey. Illustrated by Beatriz Mello (2018: 9)

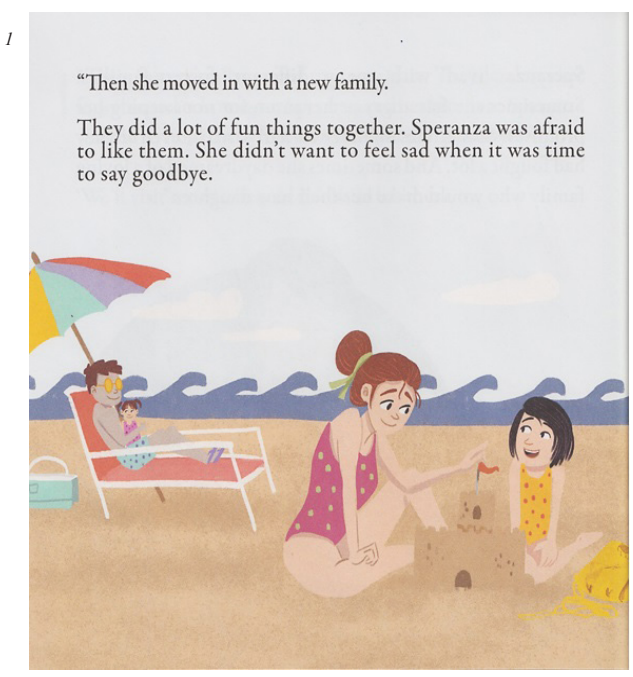

Illustration 5. Speranza at the beach with her foster family.

(C) Marcy Pusey. Illustrated by Beatriz Mello (2018: 12)

Sweater ${ }_{1}$ are Speranza's first steps, her earlier yarns which are now part and foundation for sweater $_{2}$. Sweater ${ }_{2}$ embraces past, present and future, and therefore helps the protagonist celebrate the love for her parents: "She still missed her mom and dad sometimes. She loved one set of parents and didn't stop loving the other. She loved both at the same time" (Pusey 2018: 19). The sweater as a physical object thus stands for an abstract notion, making it more accessible for the child reader to understand, discuss and remember Speranza's story, and the ideas of 'family', 'home' and 'belonging'. Sweater, ${ }_{2}$ 's pattern interweaves yarns on a striped blue-yellow design, the borders of it being of a blue colour tightening and holding it together. Their position encourages the viewer to understand one in terms of the other, to understand Speranza's past and roots in terms of her present. 


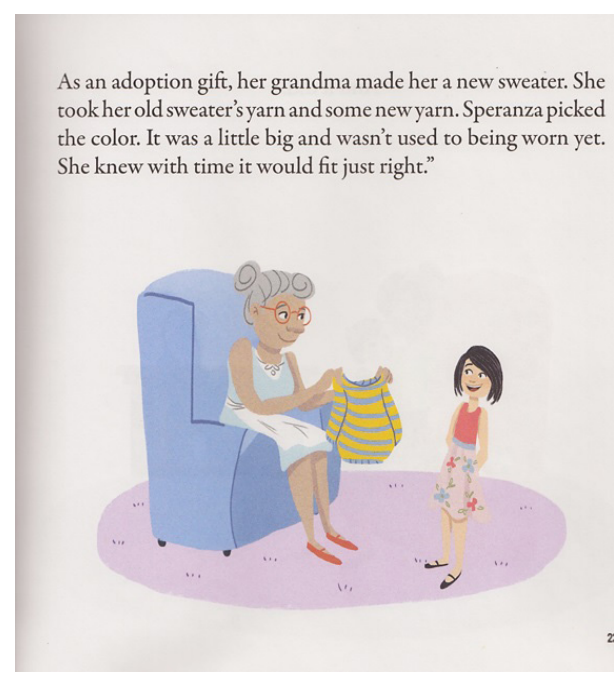

Illustration 6. Speranza's grandmother giving Speranza her new sweater, sweater ${ }_{2}$, tailored with yarns from the past and the present.

(C) Marcy Pusey. Illustrated by Beatriz Mello (2018: 23)

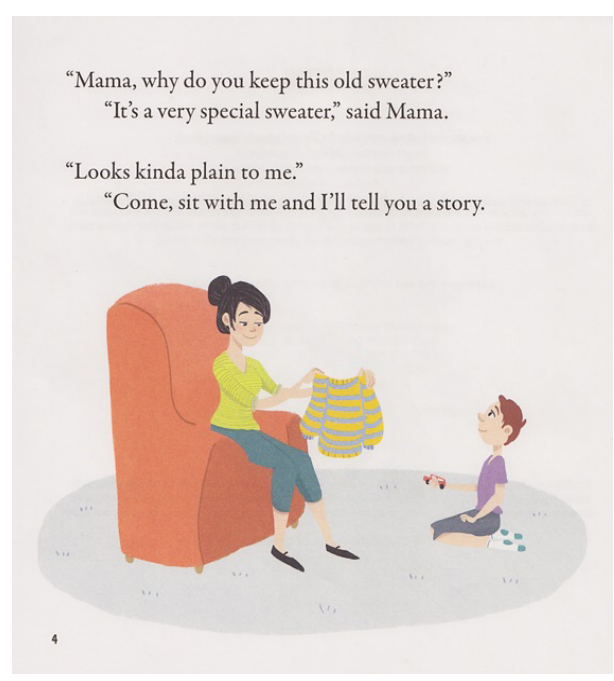

Illustration 7. A now grown-up Speranza gives sweater ${ }_{2}$ to her child.

(C) Marcy Pusey. Illustrated by Beatriz Mello (2018: 4)

The visual parallelism that joins illustration 6 and illustration 7, and consequently the participants, processes and circumstances depicted in them, is established by means of two visually rhyming scenes in a blurred context which encourages the viewer to focus on the similarities: (i) the type of furniture and their location -equally shaped sofas and circled carpet; (ii) the two participants in each picture - an adult female figure and a child, the former showing the same object ( sweater $_{2}$ ) to the latter; (iii) the almost identical position of these figures: the adult seated and the child at nearly the same hight as the sweater, either standing or kneeling (while probably playing with a toy car); (iv) the hairstyle of both female adults, tighten up in a high tight bun, as the social worker and Speranza's foster mother (Illustration 5); and (v) the context, the private environment of their houses.

Although both pictures are here displayed next to each other for contrastive purposes, in the book they feature at the beginning and end of the story, providing an associated sense of embracing the story. The likenesses encourage us to understand Speranza's present in terms of her grandmother, the passing of traditions along generations. As with textual parallelism, the attention of the viewer is grabbed due to the resemblance of both illustrations, while at the same time, $\mathrm{s} /$ he tries to establish connections amongst those visual features that differ. For instance, it could be argued that the two different colours of the armchair echo the two colours of the yarn, past and present, three generations 'weaved' together. The rhyming of colours is equally meaningful, as the sky blue colour of the grandmother's sofa matches the colour of the new yarn - of Speranza's choice- and the background colour of the book's 
front and back covers, ${ }^{33}$ while the red colour of Speranza's sofa, matches the red colour of her birthmother's sweater (Illustration 4) and her top on the adoption day.

The grandmother role as knitter likewise results from her experience and knowledge: 'She knew with time it would fit just right'. This statement, which continues with Speranza's concluding comment 'And it did', closes the story in a flashforward (Illustration 8), and is essential so as to interpret the storyline. We can argue that there is here another metaphor that extends and continues the umbrella metaphor: A LIFE STORY THAT FULFILLS THE EXPERIENCER IS A SWEATER FITTING WELL.

When we say that something 'fits', we suggest it is: [+right], [+proper], [+measure], [+shape], [+adjust]. ${ }^{34}$ We can think of 'fit' here as a transitive form in which the direct object, the person to whom sweater ${ }_{2}$ will fit with time is omitted. This omission allows a double interpretation, as on the one hand it alludes to Speranza, the person grandma thinks of when knitting sweater ${ }_{2}$, but ultimately, as the story finishes, we learn that it fits Speranza's son, and by extension Speranza herself. This open interpretation reinforces the fact that Speranza's past, present, and future is adjusted and right for her, a future in which she is able to share her life story with her son, who stands as the most significant manifestation of fulfilment. Speranza celebrates her past and present, her identity and sense of belonging. Her son now knows of it and results from it. He wears Speranza's life story.

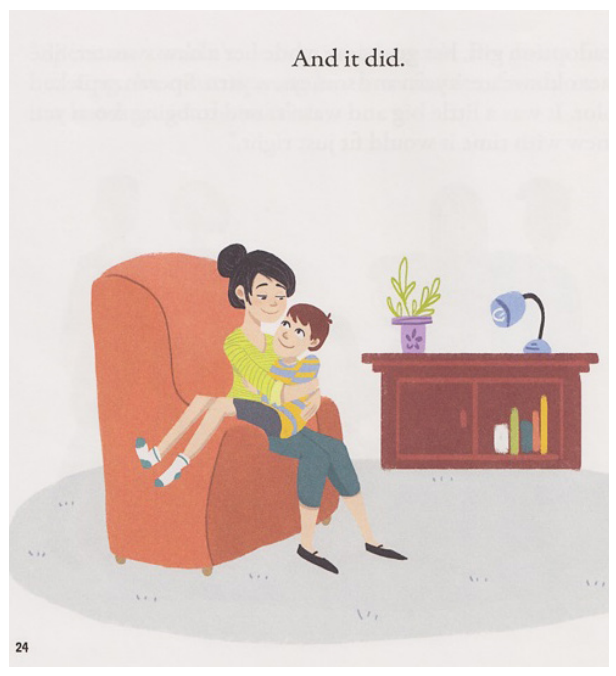

Illustration 8. It fits (C) Marcy Pusey.

Illustrated by Beatriz Mello (2018: 24)

33 The front and back covers of the book are of a sky blue color, contrasting with the yellow colour of Speranza's Sweater. Its yarn folds out of the jumper to delineate high up the title of the book. It seems that the blue colour -and by extension the adoptive family that awaits her- embraces and comforts Speranza's from the start.

34 The sense the OED specifies for 'fit' (v.) and applies to the story is 'to be the right measure or proper shape and size for; to be correctly shaped or adjusted to. Said esp. of dress; also figurative'. 
The story thus develops departing from the moment in which Speranza shows sweater ${ }_{2}$ to his son (illustration 7), and moves into a flashback of Speranza's story to later shift again to a flashforward (illustration 8). We could thus argue that the story in itself is woven, reinforcing the understanding of a life as a pattern of experiences. Social worker Jees (2009) highlights the value of life stories in adoption and foster care experiences and suggests an inverted order as the preferred option so that children would learn about their life story from the safety of the adoption that would then open other previous moments, maybe of uneasiness, prior to adoption. In this respect, Speranza's Sweater favours the inverted order, as opposed to the chronological one. Despite the book cover shows a concerned image of Speranza in her yellow sweater, the inner book story departs from the comfort of adult Speranza's home in the company of her son.

\begin{tabular}{|c|c|c|}
\hline Pages & $\begin{array}{l}\text { Description and analysis. Reference to visual } \\
\text { rhetorical devices and elements of interpersonal visual } \\
\text { representation. }\end{array}$ & $\begin{array}{l}\text { Keywords included in } \\
\text { the specification of the } \\
\text { domain sweater }\end{array}$ \\
\hline $\begin{array}{l}\text { Dedication } \\
\text { page }\end{array}$ & $\begin{array}{l}\text { First time the viewer sees sweater. }{ }_{2} \text { Here, standing } \\
\text { on its own as a visual metonymy of Speranza or } \\
\text { even more accurately, any child who can fit in it, like } \\
\text { Speranza's son. As we learn through the storyline, } \\
\text { it represents a life carefully tailored in meaningful } \\
\text { experiences in which the child also has a voice. }\end{array}$ & $\begin{array}{l}\text { Identity } \\
\text { Fulfilment } \\
\text { Belonging }\end{array}$ \\
\hline p.4 & $\begin{array}{l}\text { Speranza introduces sweater to her son. From this } \\
\text { moment onwards, she becomes the narrator of her } \\
\text { own life story, which is sometimes also narrated } \\
\text { via (free) direct speech when the son [one of the } \\
\text { addressees of this story] interrupts the narration in } \\
\text { excitement or to ask for a clarification. She decides to } \\
\text { tell him about it when her son is around the age she } \\
\text { was when having to leave her birth home (see visual } \\
\text { parallelism Illustrations } 6 \text { and } 7 \text { ). }\end{array}$ & $\begin{array}{l}\text { Special moment } \\
\text { Adoption gift } \\
\text { Through visual } \\
\text { parallelism: } \\
\text { Speranza's } \\
\text { grandmother } \\
\text { Hands }\end{array}$ \\
\hline p. 23 & $\begin{array}{l}\text { Speranza's grandmother gives sweater } 2 \text { to her } \\
\text { granddaughter as an adoption gift. They are probably } \\
\text { in the comfort of the grandmother's home. She is } \\
\text { seated in the armchair holding the sweater with her } \\
\text { two hands, the ones that knitted Speranza's memories } \\
\text { and envisaged her future. Speranza looks at her with a } \\
\text { wide smile. The scene is framed with a rounded carpet } \\
\text { (see visual parallelism Illustrations } 6 \text { and 7). }\end{array}$ & $\begin{array}{l}\text { Adoption gift } \\
\text { Speranza's } \\
\text { grandmother } \\
\text { Hands } \\
\text { Special moment }\end{array}$ \\
\hline
\end{tabular}




\begin{tabular}{|l|l|l|}
\hline Pages & $\begin{array}{l}\text { Description and analysis. Reference to visual } \\
\text { rhetorical devices and elements of interpersonal visual } \\
\text { representation. }\end{array}$ & $\begin{array}{l}\text { Keywords included in } \\
\text { the specification of the } \\
\text { domain } \text { sweater }_{2}\end{array}$ \\
\hline p.24 & $\begin{array}{l}\text { Speranza, in the intimacy and shelter of their home, } \\
\text { hugs his son, who is now wearing sweater }{ }_{2} \text {. The } \\
\text { context is the same as for p.4., we know it is a } \\
\text { continuation of the moment after having just finished } \\
\text { the story. We can now see some more information } \\
\text { about the environment with a piece of furniture } \\
\text { with some books, a lamp and a plant which point } \\
\text { at Speranza's hobbies. Plants as well as a piece of } \\
\text { paper and colour pencils also feature respectively at } \\
\text { Speranza's foster parents' house and Speranza's room. }\end{array}$ & $\begin{array}{l}\text { Special moment } \\
\text { Adoption gift } \\
\text { Through visual } \\
\text { parallelism: } \\
\text { Speranza's } \\
\text { grandmother }\end{array}$ \\
$\begin{array}{l}\text { Hands } \\
\text { Love } \\
\text { Passing of generations }\end{array}$ \\
\hline
\end{tabular}

Table 6. Visual representation of sweater ${ }_{2}$.

Taking in consideration the specification of the domains 'sweater' and 'life story' (Table 3), and very importantly, the textual (Table 4) and visual (Table 5 and Table 6) ad hoc reconceptualization of sweater ${ }_{1}^{M}$ and sweater $_{2}{ }^{M}$, we can then understand the restructured $\mathrm{D}_{\mathrm{t}}$ or $\mathrm{D}_{\mathrm{t}}^{\mathrm{M}}$ in SPERANZA'S PAST IS SWEATER ${ }_{1}$ as:

$\left[1_{t}^{\mathrm{M}}\right]$ Speranza's lifestory is partly made/enriched by several caregivers.

$\left[2_{t}^{\mathrm{M}}\right]$ It is a very special lifestory.

$\left[3_{\mathrm{t}}^{\mathrm{M}}\right]$ Speranza's lifestory includes experiences sometimes loosely woven and lost.

$\left[4_{t}^{\mathrm{M}}\right]$ Speranza's birth home and family accompanies her all along the way.

Finally, and as for the overarching metaphor running in the text, SPERANZA's PAST, PRESENT AND FUTURE IS SWEATER ${ }_{2}$, which could be extended together with the former one to A LIFE STORY (OF A CHILD IN FOSTER CARE OR ADOPTION) IS A SWEATER, the restructured $\mathrm{D}_{\mathrm{t}}$ or $\mathrm{D}_{\mathrm{t}}^{\mathrm{M}}$ can be specified as:

$\left[1_{t}^{\mathrm{M}}\right]$ Speranza's lifestory is made of old and new experiences, of various colours, linked to her birth and adoptive family, (grand)parents and siblings.

$\left[2_{t}^{\mathrm{M}}\right]$ Some of Speranza's life experiences were a bit rough, others fulfilling; some were lost in the way, others cherished and kept.

$\left[3_{t}{ }^{\mathrm{M}}\right]$ Speranza's lifestory takes a meaningful turn on her adoption day, a turn of her choice.

$\left[4_{t}^{\mathrm{M}}\right]$ Speranza's lifestory is partly knitted (and foreseen) by her adoptive grandmother.

$\left[5_{t}^{M}\right]$ Speranza's grandmother, and by extension her adoptive family, provides warmth and care, as well as the insight to celebrate all her selves.

$\left[6_{t}^{\mathrm{M}}\right]$ Some of the foreseen stories were a bit big at the time, but later came to be in Speranza's son. 


\section{CONCLUSION}

This paper ultimately aims at identifying patterns of metaphorical reconceptualization in adoption and foster care narratives, and thus further understanding the multimodal nature of this discourse. In this respect, two major conclusions can be drawn. Firstly, the life of a child in adoption and foster care system is complete, made of an array of life experiences that can be intertwined in the comfort of home, creating a sense of belonging. This can be seen in the visual and textual presentation of two ad hoc source domains, the choice of colours and rhyming similarities, the visual parallelism as well as the information that is only visually displayed. Secondly, and as a society, we are all in the role of knitters of children's life experiences, making us aware of the responsibility that this position entails, as well as each other potential to become helpers. The role of the grandmother as Knitter has a literal and figurative depiction, in the physical union of the yarns and the gift of love that helps Speranza delineate her own identity. Grandparents prove again to play a major role not only as teachers of ancestral skills such as knitting, but also of a still more ancestral value which is that of caring.

In terms of methodology, the combination of a diachronical dictionary, such as the OED, and the collocations traced by an online corpus and platform, like the iWeb (Mark Davies), have proven to be useful tools to enrich the in-depth in the specification of the domains as ready-made concepts, and thus the later transfer process. Their unified use allow us to record, respectively, the insight of lexicographers together with the more contemporary everyday use of the words which, despite being part of our (shared) background knowledge, might not be documented in dictionaries. In relation to the iWeb, the tool 'browse' and its automatic recognition of collocates and their associated KWIC was also useful to identify the lexical sets that evolve around the word-form. This analysis can be argued to offer a more comprehensive view of the domains via their semantic preference.

Romero and Soria's framework (1997, 2005a, 2007, 2014 and 2016) was key to understand in which ways the two domains, source and target, overlap; which are the particular features that are either activated or downplayed in the source domain and which are the terms at play in the reconceptualization of the target domain. Furthermore, an innovation in their model of novel metaphor is the scholars' extension of ad hoc concepts to source domains in a way that the text also constructs a temporary and non-lexicalised concept and it is this ad hoc concept the one that is used so as to reconceptualise the target. The use of an ad hoc source domain has been clearly proven in SS, in a story in which we can even identify two ad hoc source domains: sweater $_{1}$ and sweater $_{2}$. It is not a 'kinda plain' sweater that is used to describe Speranza's experience through the adoption and foster care system, but two sweaters with characteristics that are carefully added to them along the story, both in the text and the visuals, which allow us to comprehend the ad hoc reconceptualization of the life of a child in the context of adoption and foster care. In this sense, the delineation of domains, following Forceville $(1994,2008)$ and Forceville and Urios-Aparisi (2009)'s definition of multimodal metaphors, likewise acknowledges those features that are visually represented, such as the intratextuality of the teddy bear, which we can understand to be one of the special items alluded in the text: 'along with a few special items, she brought her favourite sweater'. The multimodal construction of the metaphorical 
domains thus favours the child's understanding. The role of the adult reader may here be essential to guide the child viewer.

Metonymy has likewise proven to be a key rhetorical device in the story, both textually and visually, fulfilling different functions: (i) widen the public who can wear sweater 2 by presenting it in isolation and on its own, any child or any adult's former child can feel identified, any child can wear this jumper; (ii) highlight emotions- the comforting and healing power of a story, the role of a story that 'warm[s] your heart'; (iii) contextualising but at the same time blurring some information - Speranza's birth home; (iv) merging Speranza's past and present: the jumper and the teddy bear as Speranza's birth home.

Analysing Speranza's Sweater (SS) metaphoric representation of adoption and foster care involved a study of the whole book, including the dedication page, back cover, glossary and author's note. Even though it is sometimes difficult to decide on whether to include sections that are not part of the body of the text, noticing the linguistics and visual choices in sub-corpora (SSd), (SSbc), $(\mathrm{SSg})$ and (SSan), proved to be relevant to identify meaningful vehicles running in both the overarching and related minor metaphors in the storyline. The analysis likewise supports the initial hypothesis that these sections are targeted to the adult readers, in contrast to the inner body of the text, and should then be distinguished as subcorpora so as to always interpret data in relation to the intended addressee.

The visual representation significantly strengthens the delineation of sweater sind $_{1}$ sweater $_{2}$ as ad hoc source domains. In this sense, intratextuality turns out to be a key metaphorical device. It is via the visual mode that we learn all the many occasions in which sweater ${ }_{1}$ was worn or, even just carried along, and the extent to which it progressively looses yarn. In this respect, the use of visual hyperbole for instance on pages 18 and 19, in which the yarn extends metres apart from Speranza, unaware of this and engaged in the intimacy of the prayer with her foster mother, contributes to understand the transition from sweater ${ }_{1}$ to sweater $_{2}$ in a multimodal chronical which finishes with Speranza hugging her son in the comfort of their home. Other visual devices like visual parallelism between Illustrations 6 and 7 strengthen the bonding between Speranza and her grandmother, as well as the meaning of sweater $_{2}$.

Verbalising the metaphor proved to be a complex issue. Decisions were taken on the grounds of vehicles in the corpus (e.g. 'story'), literature on adoption and foster care (Rees 2009), or visual triggers (e.g. yarn). Novel metaphors, due to their very own nature, develop our conceptual system, creating ad hoc concepts, which could well remain in us. In this light, works of art like Speranza's Sweater enrich our conceptual system, creating a more inclusive and connected society.

Acknowledgements: I would like to express my special thanks to Prof. Belén Soria (UGR) for the many occasions in which she has generously discussed their framework with me; for being the knitter of my access into pragmatics.

My gratitude likewise to the author Marcy Pusey and illustrator Beatriz Mello for very kindly granting copyright permission. 


\section{REFERENCES}

Calvo-Maturana, C \& Forceville, C. [In press C2022] 'The Depiction of Family and Self in Children's Picture Books: A Corpus-Driven Exploration'. In A. Jesús MoyaGuijarro and E. Ventola. A Multimodal Approach to Challenging Gender Stereotypes in Children's Picture Books. London: Routledge, chapter 12.

Calvo-Maturana, C. 2020. “"Born from the Heart”: Social Uses of Pictorial and Multimodal Metaphors in Picture Books on Adoption'. In Performing Metaphoric Creativity across Modes and Contexts. L. Hidalgo-Downing and B. Kraljevic Eds. Amsterdam: John Benjamins. 281-310.

Gilman, J. 2009. [illustrator K. O’Malley] Murphy's Three Homes. Washington: Magination Press. American Psychological Association.

Flowerdew, J. 2009. “Corpora in Language Teaching”. In The Handbook of Language Teaching. Long, M.H. and Doughty, C.J. Eds.West Sussex: Wiley-Blackwell, A John Wiley \& Sons, Ltd., Publication. 327-350.

ForCeVILle, C. 1994. "Pictorial Metaphor in Advertisements". In Metaphor and Symbolic Activity, 9, 1: 1-29.

ForCEVILLE, C. 2008. "Pictorial and multimodal metaphor in commercials". In Go Figure! New Directions in Advertising Rhetoric. E. F. McQuarrie, and B.J. Phillips Eds. New York: Routledge. 178-203.

Forceville, C. 2017. "Visual and multimodal metaphor in advertising: Cultural perspectives". Styles of Communication, 9, 2: 26-41.

Forceville, C. 2020. Visual and Multimodal Communication. Applying the Relevance Principle. New York: Oxford University Press.

GiBson, J. 1979. The Ecological Approach to Visual Perception. Boston: Houghton Mifflin.

Hidalgo-Tenorio, E. H. 2019. "The metaphorical construction of Ireland". In Politics, Gender and Conceptual Metaphors. K. Ahrens Ed. Houndmills and N.Y.: Palgrave Macmillan. 161-194.

Keating, J. \& Soria, B. 2019. "Populist metaphorical utterances". In Hidalgo-Tenorio, E., M.A. Benítez-Castro, and F. De Cesare (eds.) Populist Discourse: Critical Approaches to Contemporary Politics. London: Routledge, 209-226.

Kress, G. \& VAn Leeuwen, T. 2006. Reading Images. The Grammar of Visual Design, London: Routledge.

Leech, G. \& Short, M. 1986. Style in Fiction. London: Longman.

Louw, B. 1997. 'The role of corpora in critical literary appreciation' In A.Wichman, S. Fligelstone, T. McEnery, G. Knowles Eds. Teaching and Language Corpora. Harlow: Addison Wesley Longman. 240-251.

Moya Guijarro, J. 2014. A Multimodal Analysis of Picture Books: a Systemic Functional Perspective, Sheffield: Equinox. 
Moya Guijarro, J. 2015. "Visual Metonymy in Children's Picture Books". In Multimodality and Cognitive Linguistics. M.J. Pinar Sanz Ed. Amsterdam: John Benjamins.

Nikolajeva, M. \& Scott, C. 2000. “The Dynamics of Picture Books Communication”. Children's Literature in Education, 31,4: 225-239.

PAINTER, C. 2009. “Children's picture book narratives: Reading Sequences of images”. In Advances in Language and Education. A. McCabe, M. O'Donnell and R. Whittaker Eds. London: Continuum. 40-59.

Painter, C., Martin, J. \& Unsworth, L. 2013. Reading Visual Narratives. Image Analysis of Children's Picture Books. Sheffield: Equinox.

Pusey, M. 2018. [illustrator B. Mello] Speranza's Sweater. Miramare Ponte Press.

REES, J. 2009. Life Story Books for Adopted Children. A Family Friendly Approach, London and Philadelphia: Jessica Kingsley Publishers.

Romero, E. \& SoriA, B. 1997. "Stylistic Analysis and Novel Metaphor”. Pragmalingüística, 5, 6: 373-89.

Romero, E. \& Soria, B. 2005a. "Cognitive metaphor theory revisited”. Journal of Literary Semantics, 34, 1: 1-20.

Romero, E. \& Soria, B. 2005b. "I as a Pure Indexical and Metonymy as Language Reduction". In Modeling and Using Context. B. Kokinov A. Dey Ed. Springer. 436-449.

Romero, E. \& Soria, B. 2007. “A View of Novel Metaphor in the Light of Recanati's Proposals”. In Saying, Meaning and Referring. Essays on Fraçois Recanati’s Philosophy of Language. M.J. Frápoli Ed. Basingstoke: Palgrave Macmillan (Palgrave Studies in Pragmatics, Language and Cognition), 145-159.

Romero, E. \& Soria, B. 2014. "Relevance Theory and Metaphor". Linguagem em (Dis) curso, 14, 3: 489-509.

Romero, E. \& Soria, B. 2016. “Against Lepore and Stone’s Sceptic Account of Metaphorical Meaning”. Croatian Journal of Philosophy, 16, 2: 145-172.

SHort, M. 1996. Exploring the Language of Poetry, Prose, and Drama. London: Routledge.

The Collection CoramBAAF. 2017. New Beginnings and Other Writings on Being in Care. London: Coram BAAF Adoption \& Fostering Academy.

Urios-APARISI, E. \& ForCeVILle, C. 2009. Multimodal Metaphor. Berlin: Mouton de Gruyter.

\section{Software and Corpora}

Anthony, L. 2014. AntConc (3.4.3.) [Computer Software]. Tokyo, Japan: Waseda University. http://www.laurenceanthony.net/. Last accessed 11/07/2021.

English Corpora: most widely used online corpora. Billions of words of data. Free online access. Mark Davies. https://www.english-corpora.org/. Last accessed 11/07/2021. 
Mark Davies, Professor of (Corpus) Linguistics (Brigham Young University): https://www. mark-davies.info/. Last accessed 11/07/2021.

The iWeb Corpus: The Intelligent Web-based Corpus. Mark Davies: https://www.englishcorpora.org/iweb/. Last accessed 11/07/2021.

ROGET's Hyperlink Thesaurus: http://www.roget.org/. Last accessed 11/07/2021. 